\title{
Balancing a Hybrid Business Model: The Search for Equilibrium at Cafédirect
}

\author{
lain A. Davies ${ }^{1}\left[\right.$ D $\cdot$ Bob Doherty ${ }^{2}$
}

Received: 28 October 2016 / Accepted: 15 June 2018 / Published online: 30 June 2018

(c) The Author(s) 2018

\begin{abstract}
This paper investigates the difficulties of creating economic, social, and environmental values when operating as a hybrid venture. Drawing on hybrid organizing and sustainable business model research, it explores the implications of alternative forms of business model experimented with by farmer owned, fairtrade social enterprise Cafédirect. Responding to changes and challenges in the market and societal environment, Cafédirect has tried multiple business model innovations to deliver on all three forms of value capture, with differing levels of success. This longitudinal case study, therefore, provides a contribution to our understanding of how business models enact hybrid mission, providing a platform for triple-bottom-line value capture. In doing so, we are able to expand on the normative understandings of integrating hybrid objectives, and the complications of multiple types of value capture.
\end{abstract}

Keywords Fair trade $\cdot$ Hybridity $\cdot$ Hybrid organizing $\cdot$ Social enterprise $\cdot$ Sustainable business models $\cdot$ Governance . Sustainability

\section{Abbreviations \\ CPF Cafédirect producer foundation \\ CPL Cafédirect producer limited \\ FTOs Fairtrade organisations \\ NPD New product development}

\section{Introduction}

Literature has increasingly identified that social enterprises are hybrid organizations operating between different institutional logics (charity logics and commercial logics), which can conflict creating hybrid tension (Battilana and Lee 2014; Jay 2013; Santos et al. 2015; Phillips et al. 2011). A hybrid is the offspring of two different species, or varieties, and is produced when elements from the two different species are combined into one unit or organism. Hybrid organizations

Iain A. Davies

i.davies@bath.ac.uk

Bob Doherty

bob.doherty@york.ac.uk

1 University of Bath, Claverton Down Road, Bath BA2 7AY, UK

2 The York Management School, University of York, York YO10 5DD, UK thus bridge, or straddle, the conventional categories of private, public, and non-profit sectors (Austin et al. 2006; Battilana and Lee 2014; Billis 2010; Seibel 2015). Each of these sectors has a dominant logic (Thornton et al. 2012) and organizing template (Billis 2010), and most organizational forms can be readily identified as belonging to one of these sectors (Billis 2010; Haigh and Hoffman 2014; Seibel 2015).

The private sector logic prioritizes income generation from commercial activities, e.g., sales, contract fees, etc., and maximization of financial returns to shareholders. In contrast, the public sector logic is grounded in creating public benefit and the principal of collective choice. Finally, non-profit sector logic is characterized by philanthropy, advocacy, and participation (Hansmann 1980). Organizational forms that straddle institutionalized sectoral logics are labelled 'hybrid' and are found in a range of constellations such as private-public (Jay 2013; Lehner and Nicholls 2014), private-non-profit, and public-non-profit hybrids (Seibel 2015). Social enterprises, such as Cafédirect, are a classic hybrid (Battilana and Lee 2014; Dees and Elias 1998; Billis 2010) and are found in many industries such as, microfinance (Khavul 2010), energy (Rogers et al. 2012), retailing (Wilson and Post 2013), food (Doherty and Tranchell 2007), housing (Mullins et al. 2012), and health care (Santos et al. 2015). 
Battilana and Lee (2014, p. 397) introduce the concept of "hybrid organizing", defined as the activities, structures, processes, and meanings by which organizations make sense and combine multiple institutional logics. However, the field of sustainable business models has also emerged to explore how organizations adapt their business architecture to address the creation of multiple forms of economic, social, and environmental values (Bocken et al. 2014; Rauter et al. 2015). Limited research, however, has attempted to integrate these two approaches, to investigate how hybridity manifests across business models to deliver multiple forms of value (Davies and Chambers 2018; Margiono et al. 2017).

To investigate these phenomena, this paper focuses on a 17 year longitudinal case study into prominent UK social enterprise, Cafédirect. It is a farmer owned, fairtrade hot drinks social enterprise, and was the first fairtrade brand to become commonly stocked by major UK retailers. It was founded by four UK organizations involved in poverty alleviation: Oxfam (an International Charity), Traidcraft (a fairtrade social enterprise), Equal Exchange (fairtrade and organic cooperative), and Twin Trading (NGO working on market access for small-holder farmers). The mission was to pioneer fairtrade coffee and tea into mainstream distribution, whilst improving the livelihoods of small-holder farmers in developing economies.

This paper investigates the challenges of operating a hybrid enterprise over the long term. We investigate how external environmental challenges, and a drive to improve social and environmental value, led to a series of internal strategic decisions which manifest as dynamic changes to the Cafédirect business model. We provide a rare exploration into a failure to increase triple-bottom-line value [economic, social and environmental (Elkington 1997)] as a result of the lack of organizational balance. In particular, we explore why the organization's embedded hybridity causes tensions leading to this failure. In doing so, we extrapolate on the implications of trying to deliver on too many types of value (Santos et al. 2015), with too many differentiated activities that do not integrate the different forms of value (Battilana et al. 2012). Therefore, we contribute to both the literatures of hybrid organizing and sustainable business models by integrating both emerging theoretical approaches, to provide insight into the complementarity of the two fields. We show how tensions between competing logics are managed to deliver multiple forms of value capture. In doing so, we expose the vital importance of balancing societal and commercial logics effectively, to make them complementary within the value creating activities embedded within the business model.

The paper is presented in four sections. First, we synthesize the current literatures on hybridity and sustainable business models, identifying how both address similar issues in relation to the delivery of multiple forms of value, leading to our research objective to explore how strategic decisions changing the business model affect the salience of hybrid tensions, and ability to capture triple-bottom-line value. Second, we present our choice of methods, case selection, and data analysis. Fourth, we present the results of our 17 year study, documenting the environmental challenges and hybrid tensions which have driven marked periods of business model innovation. Finally, we discuss the practical and theoretical implications of this extensive case.

\section{Literature Review}

According to the European Commission (2017), a social enterprise is defined as an entrepreneurial organization that engages in economic activity and focuses on achieving wider social, environmental, or community objectives. In addition, they are independent and employ participatory governance models, and, if financial surpluses are generated, they are largely reinvested in societal objectives (European Commission 2017). Social enterprises are "not aligned with the idealized categorical characteristics" of the private, public, or non-profit sectors (Doherty et al. 2014, p. 3), and, by pursuing the combined achievement of commercial, social, and environmental value capture, are thus a classic hybrid organizational form (Battilana and Lee 2014; Defourny and Nyssens 2006; Billis 2010). By bridging institutional sectors, social enterprises draw on multiple institutional values and practices (Phillips et al. 2011). However, the conflicting logics of generating commercial value, at the same time, as generating social and environmental value, can create organizational tension (Austin et al. 2006; Pache and Santos 2013; Smith et al. 2013). Literature suggests that organizations can manage these tensions through the dimensions of hybrid organizing (Battilana and Lee 2014), or through a sustainable business model (Bocken et al. 2016; Davies and Chambers 2018). We investigate the extant literatures on each of these topics in turn.

\section{Hybrid Tensions}

Battilana et al. (2012) and Ebrahim et al. (2014) address the issue that many social enterprises' have different organizational activities relating to their commercial and societal value creation. Both papers identify two types of hybrid venture: integrated hybrids, where social and environmental impact is often served through the same activities as economic value creation, and differentiated hybrids when social and environmental value creation requires additional organizational activities to the economic value creation. This second type is particularly prevalent where the social enterprises' beneficiaries are different to the social enterprises' customers (Santos et al. 2015). Structural separation 
is the commonly suggested solution, in which the two sets of activities are decoupled into compartmentalized subunits to negate this tension (Battilana et al. 2012; Mason and Doherty 2016). Conversely, Battilana et al. (2012) suggest hybrids should try to find mechanisms to integrate these differentiated activities, leading to commercial and societal benefits simultaneously. However, as organizations have limited resources, different value creation activities may still compete for these scarce resources, particularly, financial, physical, human, and network capital.

The multiple potential missions in social enterprises causes tensions in the available sources of financial and costs of physical resources (Austin et al. 2006; Dacin et al. 2010). Research has noted that social enterprises have access to fewer resources than commercial ventures, because those controlling resources (such as investors) are uncertain about how the organization will combine the social objectives with a financial return (Austin et al. 2006; Hansmann 1980; Seelos and Mair 2005). Social enterprises also often purposefully pay more for their raw materials due to their relationships with beneficiary groups, and thus have higher costs of goods than commercial rivals, e.g., fairtrade (Hockerts 2015). To respond to the negative impact of social mission on access to resources, social enterprises draw on novel resource acquisition strategies such as bricolage, where they create value by combining a range of existing but undervalued resources, e.g., relationships with beneficiaries (Desa and Basu 2013; Di Domenico et al. 2010). There is also a growth in sources of social finance and crowd funding to alleviate financial capital limitations (Lehner and Nicholls 2014); however, access to these can be limited (Davies et al. 2018).

Tensions are also present in how social enterprises manage human resources. Recruitment is shaped by the skill requirements of the social enterprise (Smith et al. 2012). For example, in work integration social enterprises, usually only disenfranchised members of society (offenders, homeless, disabled, etc.) are recruited to deliver on social and/or commercial objectives (Pache and Santos 2013). For social enterprises that do not rely on donations or grant funding for survival [termed earned income by Defourny and Nyssens (2008)], Battilana and Dorado (2010) found that trying to recruit employees with similar identities and goals to the enterprise was often a difficult task. Conversely, a study of employment and motivation in community finance organizations found that employees who had previously worked in private sector finance accepted reduced remuneration in exchange for a personal desire to work for an organization that provides benefits for society (Bell and Haugh 2014). A study of the hybrid Wholefoods (USA) found that managers who embrace the competing logics inherent to hybrid organizations are less likely to create internal conflicts (Besharov 2014). However, hybridized individuals are not usually easy to find, as most people are still socialized into one dominant employment sector. A number of authors, therefore, suggest various approaches for the socialization of employees to assist in embracing the logics including creating spaces for negotiation, induction with beneficiaries, and control systems that embrace both aspects (Battilana and Dorado 2010; Santos et al. 2015).

In terms of network capital, relationships with stakeholders are an important resource for creating value, because they allow enterprises to acquire scarce resources, as well as gain access to markets, and create greater social impact (Austin 2010). Alliances range from formal cooperative structures such as joint ventures, partnerships, licensing (Austin 2010), and social franchising (Tracey and Jarvis 2007), to less formal mechanisms such as sharing ideas freely and allowing others to scale up an innovative approach (Lyon and Fernandez 2012). However, social enterprises have a challenge in establishing their legitimacy with different stakeholders (Kraatz and Block 2008; Zuckerman 1999). Crucke and Knockaert (2016) in their study of WISEs in Belgium found that boards that appoint representatives from different stakeholder groups have been found to encounter fault lines between the interests of different subgroups. This may render the social enterprise hybrid slow to respond to opportunities or threats and impact on commercial, social, and environmental goal achievements. Communicating effectively with these partners can also be problematic due to different terminology across different logic organizations (Teasdale 2012), and some stakeholders struggle to understand the multiple types of value that the social enterprise is attempting to create. For example, in cooperative hybrids, external stakeholders such as financial investors, or business partners have particular commercial expectations which may conflict with the needs of the enterprises' beneficiaries (Santos et al. 2015). The choice of partners for social enterprises can, therefore, be problematic, because legitimacy with other stakeholders is influenced by the reputation of the chosen partner (Austin et al. 2006; Moizer and Tracey 2010). Close relationships with organizations embedded in more established sectors can assist social enterprises in accessing needed resources (Austin 2010). However, some partners can compromise the social enterprises' hybrid nature (Smith et al. 2012).

The need to satisfy a wide array of external stakeholders produces tensions which pervade across the entire organizations business model (Lumpkin et al. 2013; Mason and Doherty 2016). Nevertheless, responding appropriately to the demands of different stakeholder groups has been associated with strategic effectiveness (Battilana and Dorado 2010; Brown and Iverson 2004). Stakeholders, therefore, play a key role in shaping management direction, which can create greater tensions between the social and commercial objectives (Teasdale 2012). 


\section{Hybrid Organizing}

Empirical studies on managing conflicting demands are few. However, the implications of a failure to manage hybrid tensions emerge from a number of studies. For instance, an analysis of two microfinance organizations found that intractable identity conflicts between banking and development logics led to "an impasse which made it impossible to operate effectively" (Battilana and Dorado 2010, p. 1427). The impasse was resolved after staff resignations, dismissals, and strategic reorientation. Conversely, Phillips et al. (2011) document the demise of Aspire (a mail order catalogue) attributing it to the prioritization of social mission above commercial sustainability. These failures highlight the difficulty social enterprises have in mitigating hybrid tensions.

Battilana and Lee (2014), in their conceptual paper, propose five dimensions of hybrid organizing to manage hybrid tensions: (1) organizational activities, (2) workforce composition, (3) organizational design (4) culture, and (5) interorganizational relationships, many of which are alluded in Sect "Hybrid Tensions" above. In essence, Battilana and Lee (2014) address the issue that to maintain legitimacy, hybrids need to maintain appeal to multiple audiences by integrating activities, resources, structure, culture, and partners. Integrated approaches can be found in the business models of Grameen microfinance where the beneficiary and customer are one and the same (Khavul 2010), or in sustainable entrepreneurs where disrupting markets with more sustainable alternatives, provides both more sustainable consumption, and revenue for the enterprise (Davies and Chambers 2018). Through integrating the five dimensions of hybrid organizing to deliver multiple forms of value simultaneously, organizations are more likely to be recognized as legitimate members of multiple institutional forms (Battilana and Lee 2014). However, for some social enterprises, their social and commercial activities are not integrated, but differentiated (Battilana et al. 2012). If you take Shoreditch Development Trust (London), for example, their commercial activity is renting workspace via regenerated buildings, which fund entirely separate activities with various community projects for disadvantaged groups. The separated activities can lead to trade-offs between the subunits that compete for similar resources (Arradon 2007). Jay (2013) introduces the concept of the 'service paradox', whereby trying to serve one constituency can, therefore, involve failing to adequately serve another one. Navigating this service paradox by developing selective approaches to integration can be helpful (Ebrahim et al. 2014). At a leadership level, managers who embrace the competing logics limit conflict (Besharov 2014; Waldman and Bowen 2016). However, there has been limited empirical investigation on the process and conditions for integration, or on communicating this integration to stakeholders (Dey and Teasdale 2016).
Battilana and Lee (2014) suggest the dimensions of hybrid organizing constitute organizational features that can be, to a lesser or greater extent, integrated to respond to social and commercial logics. A more nuanced approach; suggested by Santos et al. (2015), however, is to consider not the mission logics, but the type of value capture. Rather than focusing on individual dimensions of hybrid organizing to overcome tensions, this view looks at the alignment of the business model towards creating and capturing multiple types of value. They focus particularly on the extent to which societal value can 'spillover' from the commercial activities. This views organizations as not having a singular societal and singular commercial logic, but potentially multiple forms of value creation happening simultaneously. Santos et al. (2015), therefore, identify that societal value can be an automatic spillover from commercial activities, e.g., paying a fairtrade premium to producers, but can also be a contingent spillover, requiring third parties to develop interventions to ensure societal benefit, such as funding a charity who provide work place support and training for disadvantaged members of society. The overall alignment of the business model to facilitate the spillover of societal value, in the view of Santos et al. (2015), becomes more fundamental than the logics underpinning the desired value.

\section{Sustainable Business Models}

The term 'business model' has been applied as a generic term to describe how social enterprises are managed by a number of authors including Santos et al. (2015), Hahn and Ince (2016), and Wilson and Post (2013). However, social enterprise researchers are only now attempting to integrate the hybrid organizing and business models literatures from a theoretical perspective (Davies and Chambers 2018).

Despite the often generic uses of the term leading to conceptual confusion (Osterwalder et al. 2005), business models (as a theoretically defined field) describe the organizational architecture which sits between strategy and activities (Osterwalder et al. 2005; Teece 2010). As such, it forms the basis for understanding how an organization positions itself to create and capture value in a market (Stähler 2002; Rauter et al. 2015). Business models are a representation of the approaches that organizations develop to deliver the value that they intend to capture (Boons and Lüdeke-Freund 2013). Traditionally, this theory has been applied to economic value capture (Teece 2010), but, in recent years, there has been a shift to consider economic, social, and environmental value capture through the emergence of sustainable business models research (Boons and Lüdeke-Freund 2013; Zott et al. 2011). This stream of research seeks to understand how organizations embed sustainability as part of a triplebottom-line value creation and capture approach. 


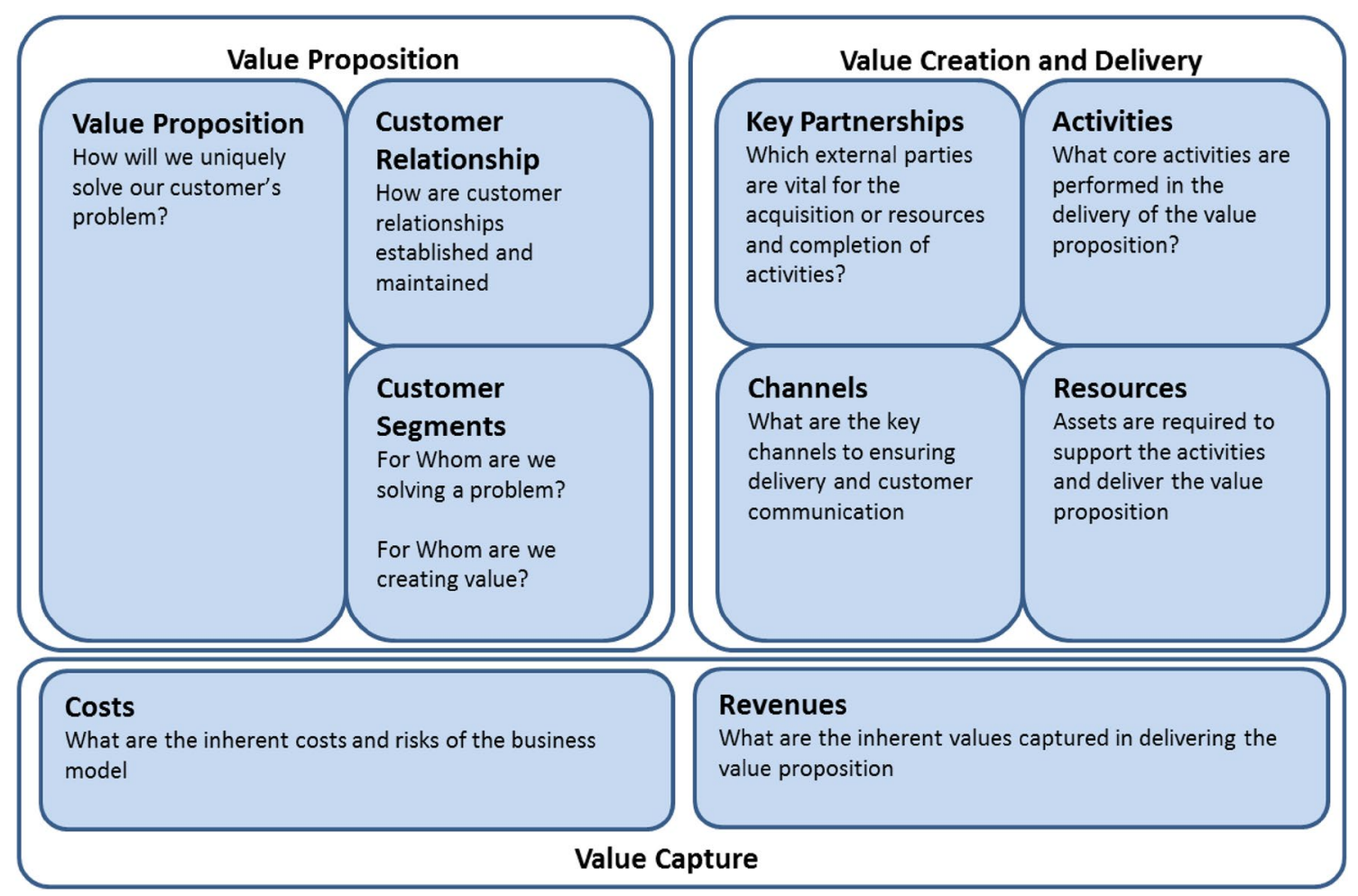

Fig. 1 Business model canvas synthesized from Osterwalder and Pigneur (2010) and Bocken et al. (2014)

Sustainable business model theory has predominantly explored economic value-driven organizations' movement towards more sustainable business practice (Boons and Lüdeke-Freund 2013). This field demonstrates that a successful transition to more sustainable business practice requires a robust business model which targets integrated activities towards automatic spillover type triple-bottom-line value creation (Baumgartner and Ebner 2010; Bocken et al. 2014). However, limited research has empirically explored organization set up with triple-bottom-line value capture at their core, such as social enterprises (Lüdeke-Freund et al. 2017; Margiono et al. 2017), and none explore hybrids with differentiated activities, or contingent value spillover (Davies and Chambers 2018).

Despite a lack of theoretical integration, normative analyses of sustainable business models often turn to social enterprises in their description of sustainable business model archetypes (Boons and Lüdeke-Freund 2013; Bocken et al. 2014; Grassl 2012). Grassl (2012) provides the most explicit exploration of social enterprise business models by presenting a series of different interactions between beneficiaries, social enterprises, and the market, as a means of distinguishing high-level manifestations of a social enterprise business model. Although the exploration is at a high level of abstraction, it shows the strong overlap between dealing with hybrid tensions and ensuring that an appropriate business model emerges. Bocken et al. (2016) go one step further and explore how business model innovation-the process of creating or transforming a business model-is at the heart of success in three large, well-documented social enterprises (Amul, Aravind and BRAC). All of which could be broadly termed integrated hybrids (Ebrahim et al. 2014), with largely automatic value spillover (Santos et al. 2015). However, we once again see the benefit of mapping the business model for understanding triple-bottom-line value capture.

What constitutes the core elements of a business model is founded on Osterwalder et al.'s (2005) identification of the building blocks of business models (value propositions, target customers, distribution channels, market relationships, value configuration, core competency, partner network, cost structures, and revenue model). These were coalesced by Osterwalder and Pigneur (2010) into the business model canvas. In Fig. 1, the nine elements of Osterwalder and Pigneur (2010) business canvas have been grouped based on Bocken et al.'s (2014) reorganization of the business model building blocks into their three core elements of Value Propositions, Value Creation and Delivery, and Value Capture dimensions. This business model canvas has been frequently used in the literature to explore successful business models directed at sustainable value capture (Franca et al 2016; Geissdoerfer et al. 2016; Joyce and Paquin 2016). Some such as Joyce and Paquin (2016) create different canvases for economic, social, and environmental value capture, indicating the potential for exploring differentiated hybrids, although this appears 
to be at odds with the overall idea of a holistic business model targeting triple-bottom-line value capture (Boons and Lüdeke-Freund 2013). In this paper, we, therefore, focus on the business model canvas as presented in Fig. 1 as the basis for understanding how hybrid tensions can be both magnified and addressed, through business model innovation. In particular, we focus on how changes in the external environment, and internal decision-making, towards more differentiated activities and multiple forms of value capture manifest in a reshaping of the business model. We also then demonstrate how business model innovation can help to realign activities to ensure a better integration towards delivering automatic and contingent value spillover.

The research objective of this paper is, therefore, to explore how decisions which change the business model at social enterprise Cafédirect affect its ability to manage the hybrid tensions and multiple forms of value capture. In doing so, we expose the vital importance of balancing societal and commercial logics effectively, even when there are differentiated activities producing both automatic and contingent value spillover. We show how a deficiency in integration across the activities leads to near failure, and how rebalancing the activities through structural separation, and the explicit identification and management of differentiated activities has led to recovery.

\section{Methodology}

The exploratory nature of the research question favors a phenomenological approach to data collection (Miles and Huberman 1994). A single longitudinal case study is justified on the basis of both the revelatory nature of the case (Yin 2003), the longitudinal nature of business model innovation, and the privileged access to data allowing deep insight into a complex and highly nuanced field of study (Glaser 1992).

\section{Case Selection}

Cafédirect provides a clear context for investigating sustainable business models and managing hybridity-derived tensions. Founded in 1991 by four mission driven organizations (see "Introduction"), Cafédirect was subject to a marketing and networks based case study in Journal of Business Ethics in 2010 (see Davies et al. 2010). Cafédirect's core economic activity (selling hot drinks) is undertaken as a tool to serve the social goals (empowering small-holder farmers and pulling them out of poverty) and more latterly environmental goals (climate change adaption in growing communities and creating zero-carbon supply chains). Table 1 provides information on the company today.

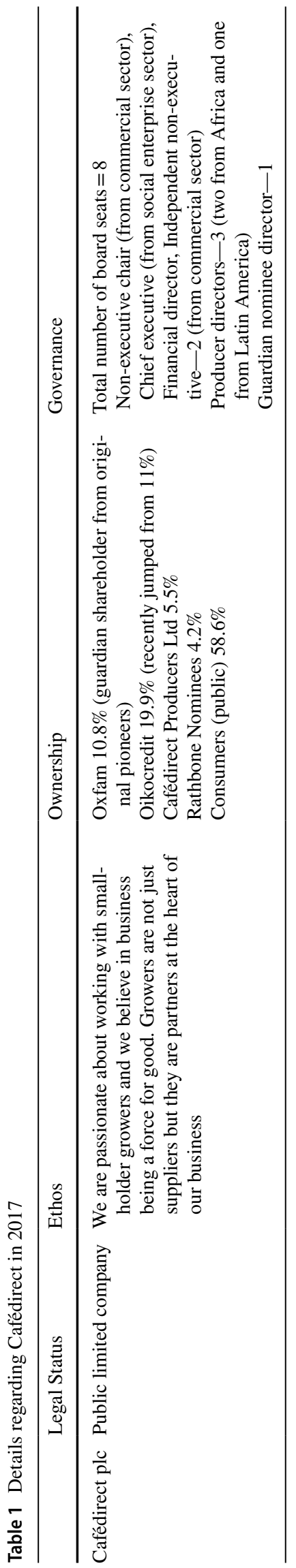


Table 2 Data collected across the three periods

\begin{tabular}{|c|c|c|c|}
\hline & $2000-2003$ & 2004-2009 & 2013-2017 \\
\hline Head office observation & 2 visits, $(\sim 120 \mathrm{~h})$ & 4 visits, $(\sim 100 \mathrm{~h})$ & 5 visits $(\sim 130 \mathrm{~h})$ \\
\hline Other observation & $\begin{array}{l}\text { Touring with the marketing team } \\
\text { at public events such as the } \\
\text { Edinburgh Fringe festival and } \\
\text { retailer visits In Scotland and } \\
\text { Wales }(\sim 100 \mathrm{~h})\end{array}$ & $\begin{array}{l}\text { Direct observation of three annual } \\
\text { general meetings from } 2006 \\
\text { to } 2008 \text { and associated notes } \\
\text { and informal discussion with } \\
\text { employees and shareholders } \\
\text { Plus direct observation at ten pub- } \\
\text { lic fairtrade fortnight campaign } \\
\text { events including discussions } \\
\text { with employees and supporters } \\
(\sim 130 \mathrm{~h})\end{array}$ & $\begin{array}{l}\text { Direct observation of eight annual } \\
\text { general meetings from } 2009 \\
\text { to } 2016 \text { and associated notes } \\
\text { and informal discussion with } \\
\text { employees and shareholders } \\
\text { Direct observation and informal } \\
\text { interviews with producers at the } \\
\text { Cafédirect Producers conference } \\
\text { Entebbe, Uganda March } 18-19 \text { th } \\
2013 \\
\text { Direct observation of } 15 \text { fairtrade } \\
\text { campaign events including infor- } \\
\text { mal discussions with employees } \\
\text { of both Cafédirect and their } \\
\text { supporters }(\sim 200 \mathrm{~h})\end{array}$ \\
\hline Formal interviews with Cafédirect & 12 interviews & 13 interviews & 11 interviews \\
\hline $\begin{array}{l}\text { Formal interviews with Cafédi- } \\
\text { rects partners and customers } \\
\text { about Cafédirect }\end{array}$ & 8 interviews & 14 interviews & 7 interviews \\
\hline
\end{tabular}

The case is particularly revelatory as it provides insight into the challenges of managing a hybrid organization over the long term, as the internal and external environments change. The case organization has three clearly identifiable periods of business model innovation over the timeframe of data collection, which form the basis for the case presentation below. Periodization is a qualitative historical research approach for condensing complex temporal data into sequential time periods with fairly distinct start and end points (Witkowski and Jones 2006). Here, we follow that Hollander et al. (2005) suggest of periodization based on turning points in the narrative of the study context; rather than discrete periods of time, to more accurately convey the key turning points in Cafédirect's business model. These involve not only changes in the structure, and branding of the enterprise, but also major changes in its objectives related to social and environmental value spillover, and level of integration of commercial versus societal activities (Hollander et al. 2005).

\section{Data Collection}

The data used in this case study draw on an ongoing 17 year qualitative study into the organization. The commencement of this study predates both the emergence of hybrid organizing and sustainable business models literatures, but the deep and ongoing nature of the data collection allows for revisiting issues of hybridity and the organizations evolving business model throughout the study period. The longitudinal case study approach draws on qualitative data (observation, interviews, and attendance at corporate events such as
Annual General meetings and field visits to producer communities), and secondary data (annual reports, shareholder documents, internal company reports, market performance data, statistics, and surveys) providing information of relevance to the study (Goulding 2001; Yin 2003). Table 2 provides a summary of the qualitative data collected over the duration of this study.

Distinct periods of formal data collection have been undertaken, utilizing mixed qualitative methods (see Table 2). In addition, both authors have continuously worked in and researched the sector for over 20 years. Participant and personal observation were recorded through formal and reflexive research diaries and audio recordings. Although formal recording of this specific phase of data collection is blurred by the ongoing nature of the study, approximately $800 \mathrm{~h}$ observation has occurred over the 17 years.

A total of 36 semi-structured key informant interviews with Cafédirect employees from senior management groups, sales and marketing teams, and supply-chain department have occurred over the period, with incalculable informal interviews and discussions, both face-to-face and via telephone. In each phase, the chairperson, managing director/ $\mathrm{CEO}$, and marketing/commercial director at the time have been interviewed, as well as relevant other employees based on a snowballing approach guided by the relevant issues of the time, including marketing managers, logistics managers, salespeople, head of sustainability, and those working with producer groups. In addition, 29 formal supplementary interviews across the marketplace from producers, supply-chain partners, retailers, and the fairtrade establishment have also informed the understanding of the periodization of business 
model. All formal interviews were recorded leading to over $80 \mathrm{~h}$ of recorded material, transcribed, and then checked by the interviewee for accuracy.

\section{Data Analysis}

To ensure internal validity and reliability, a constant comparative method was utilized (Barnes 1996). Multiple responses were compared against each other, field notes, and secondary sources. We subsequently interpreted these data outputs and provided underlying rationales for the company's actions from the data (Eisenhardt 1989). External validity and reliability was increased through triangulation with both secondary sources (news media, industry reports, internal reports, sales ledgers, etc.), third-party interview data (such as network partners), and taking versions of the work to the case organization for their feedback and comments (Askey and Knight 1999).

Interviews were transcribed and run through a series of categorization, abstraction, and comparison processes to identify themes which contribute to theory development (Spiggle 1994). Aspects of theory were then reviewed iteratively to decide on the direction of future data collection and emergent themes were then put to participants for review and refinement prior to writing the final document. It was at this later stage that the relevance of business models became apparent, and data were then reanalyzed to build the business model periodization presented below.

\section{Findings}

As discussed above, this section is organized as a periodization based on the different business models which dominated at Cafédirect over its historical phases. Figure 2 provides a summary of the movement in the value spillover, and level of integration between commercial and societal value spillover activities throughout the period of study. Period 1 (1991-2008) covers the business model which emerged through the enterprise's rapid growth phase, which was a simple integrated business model where commercial success in selling beverages was directly linked to societal value through fairtrade premiums paid to producers (automatic value spillover), and donations for producer support to Twin Trading through social premiums and profit sharing (contingent value spillover). The Davies et al. (2010) paper explores the marketing activities of period 1, and we have included the different eras of brand positioning (solidarity, development, and massmarketing) from that paper in the below figures for consistency, but Cafédirect's approach to value creation and

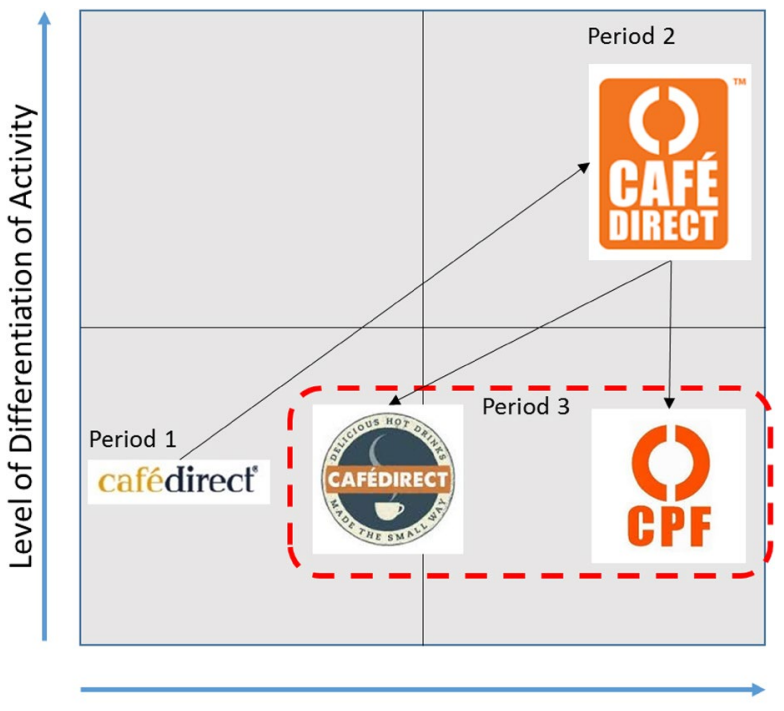

Extent of Intended Value Spill-Over

Fig. 2 Cafédirect's value spillover and business model integration over the periods

capture was effectively the same throughout this period, and thus, the business model remained consistent. Period 2 (2009-2012) follows the implications of Cafédirect taking more ownership of the activities related to its beneficiaries value creation. This led to the development of differentiated activities focusing on three different forms of value: economic (income), social (producer income and welfare), and environmental (tackling climate change), providing multiple forms of both automatic and contingent value spillover. Period 3 (2013-2017) explores the attempt to reintegrate the forms of value capture through the structural separation of some value creating activities. Although the value capture still maintained both automatic and contingent forms, the business model shows more integrated activities. The complexity and depth of data collected make exhaustive citation to sources impractical. However, indicative sources for observed or triangulated data sources are included in parenthesis.

\section{Period 1: Simple Value Creation: Integrated Business Model}

From its foundation in 1991 until 2008, Cafédirect's business model changed little, with similar intended value creation activities, and approaches to value capture. There had been a number of changes over this period, such as rebranding, increased retailer coverage, an initial public offering, and product extensions (Davies et al. 2010). Nevertheless, the integration of activities and the type of value captured were largely consistent. 


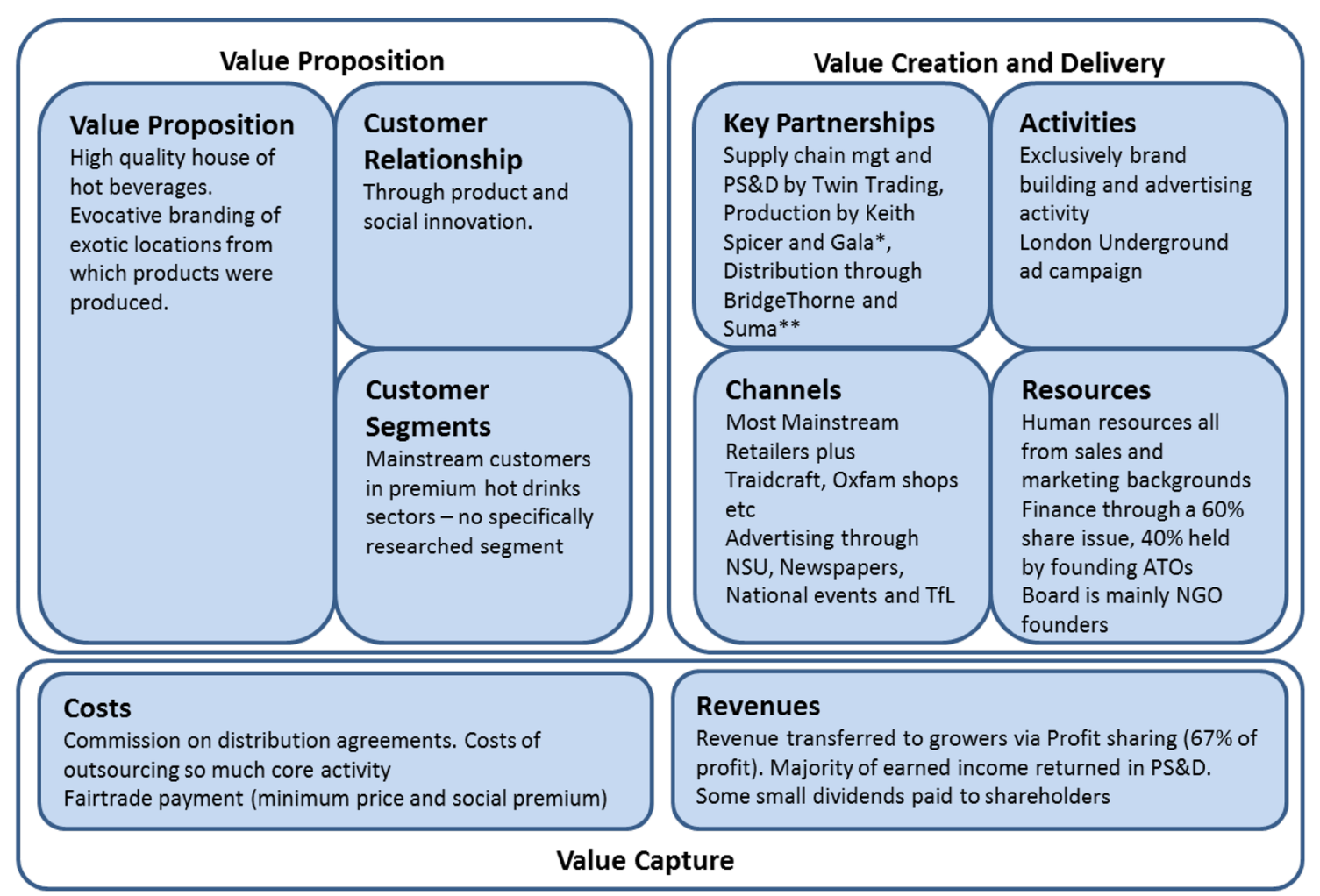

* Both UK based hot beverage manufacturers used by Cafédirect and major supermarket chains

** UKs largest wholefood wholesaler

Fig. 3 Cafédirect's business model period 1

\section{Challenges and Opportunities}

Fairtrade certification was in its infancy when Cafédirect was founded. The original mission, passed down by its four founding organizations, was to survive entirely from commercial revenue for the purpose of creating four types of societal value: protecting producer livelihoods with a minimum agreed price for coffee [following the 1989 coffee price crash which saw an $86 \%$ drop in coffee prices following the dismantling on the International Coffee Agreement (ICO 2004)], providing producers with higher long-term income and welfare provision to promote poverty alleviation through producer support and development initiatives (PSandD), educate consumers about where products come from and living conditions for producers, and "pioneering the Fairtrade Mark" into the mainstream retail marketplace (interview with the Managing Director 2001). From the start, Cafédirect always went "far beyond the minimum fairtrade standards", and minimum levels of PSandD expected of participants in the Fairtrade certification scheme (former Chairman of the Fairtrade Foundation in 2007). Cafédirect funded their own PSandD through their Gold Standard producer support pledge, administered by producer empowerment NGO Twin
Trading. Twin Trading also handled all supply-chain management, leaving Cafédirect to focus on marketing and selling (field observations and various interviews). In essence, the main function of Cafédirect was to communicate with the mainstream about fairtrade and sell as many fairtrade hot beverages as possible, to raise money to give to Twin Trading for producer support. One key informant from the supermarket sector commented in 2007:

Cafédirect was one of the first innovators in Roast and Ground coffee, highlighting the provenance of the coffee and their work with farmers, they really stood out.

\section{The Business Model}

Our interpretation of the business model canvas for Cafédirect in Fig. 3 shows that the company was running an integrated business model. Cafédirect were driven by economic value capture, automatically contributing to consumer education and pioneering Fairtrade through increased sales and distribution. Contingent value spillover in relation to PSandD through social premiums and profit sharing was administered via Twin Trading, meaning that it sits outside 
Fig. 4 Previous brand packaging (from Davies et al. 2010)

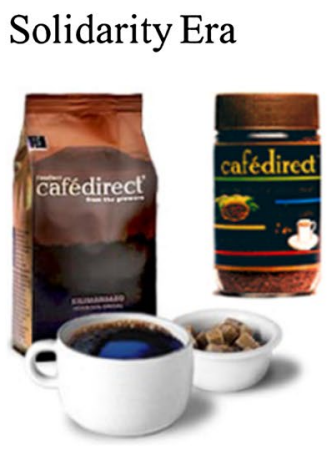

the direct activities on Cafédirect's business model. Manufacturing was also outsourced to third-party suppliers (Keith Spicer and Gala) and even retail relationships were outsourced, first to cofounder Equal Exchange, and then to sales broker Bridgethorne in the supermarket sector. Ultimately, the Cafédirect business model up to late 2008/early 2009 was simple: a brand management and marketing company, trying to maximize sales and revenue, and minimize costs to pass as much money on to Twin Trading as possible. We identify this as an integrated business model, because the economic value creation activities lead directly to the societal value. This allows Cafédirect to focus purely on the commercial business logic.

Hybrid tensions as discussed in the literature were, as such, minimal. We observed that the governance structure with NGOs, social enterprises, charities, and producers guiding the mission, a specialist partner managing contingent societal value capture, and a workforce focusing on income generation, prevented role uncertainty and potential mission drift. Human resourcing issues were relatively simple, and over the first periodization, we observed the workforce transition from people initially "requisitioned from the founders" (interview with Founder board member in 2002), to a leadership team of social mission driven people ensuring the governance of the enterprise, but supported by a workforce drawn from relevant mainstream commercial backgrounds. This appears to have ensured maximum income generation as suggested by this marketing manager, formally from Mars, in 2002:

Although this is obviously a much smaller company, so challenges are different, my job of trying to make the brand as appealing to customer as possible is the same.

Financial capital; which had become something of an issue leading into the 2000's, was addressed with an initial

\section{Market Development Era}

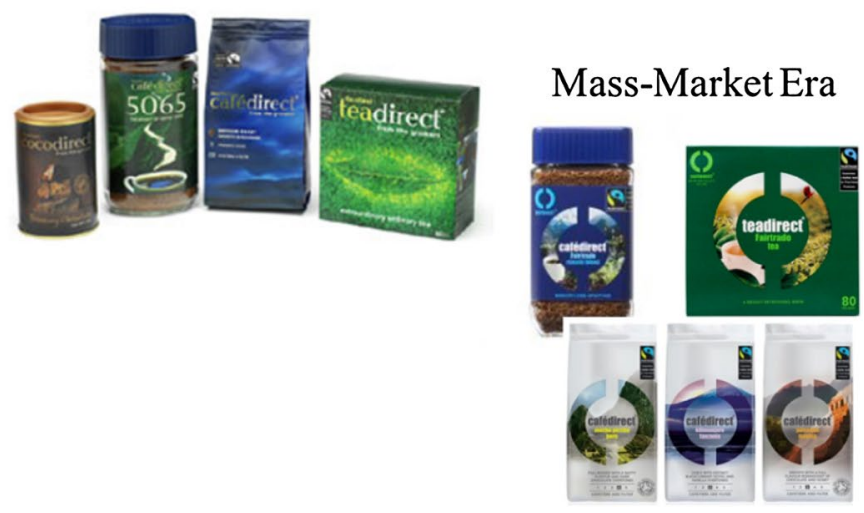

public offering in 2004, which was largely taken up by consumer supporters (Cafédirect Plc. 2004), providing something more akin to community shares, than traditionally traded stocks. Cafédirect's was a traditional commercial business model, but with an interesting story, having producers as recipients of dividends instead of shareholders. This gave them a unique value proposition for many years, gaining them access to markets, free advertising, PR, and alliance partners. A leading food journalist commented in 2006:

Cafédirect were very effective at securing mainstream media coverage in leading high quality newspapers and food magazines. They had a great brand story to tell, of doing good with coffee

Tensions related to legitimacy with external stakeholders also appeared to be well managed by this model. Marketing communications evolved to focus on product quality and evocative images of highland landscapes, leaving the Fairtrade Mark to proxy for the ethical branding (see Fig. 4 and Davies et al. 2010). The area in which tensions did emerge was in relation to the fairtrade social movement. Some fairtrade "activists", from which Fairtrade Certification had emerged, were against Cafédirect's mission of pioneering fairtrade into the mainstream, considering it a "dilution of the ethos of alternative trading" (interview with a member of Equal Exchange in 2002). Overtime fractures between Cafédirect and its founders as well as with the Fairtrade certification bodies began to emerge. One key informant at Cafédirect commented in 2009:

The tension at board level started to significantly delay decision making. We took our eye off the ball with regard to developing the brand at a time when external competition started to intensify. We should have been investing time in NPD rather than arguing at board level over governance matters 


\section{The Results}

By 2008, Cafédirect was the fourth biggest coffee brand in the UK with a turnover of $£ 22.3 \mathrm{~m}$ (Cafédirect Plc. 2009). They operated in growing markets with fairtrade growing at an average of $45 \%$ per year from 2007 to 2009 (Mintel 2008), and fairtrade coffee at $27 \%$ per year (Fairtrade Foundation 2014). Even though a 2004 public offering reduced the founders' shareholding from 25 to $10 \%$ each, the maintenance of a "golden share"; which could veto any social mission affecting decision, plus the provision of shares and board seats to producer groups, meant mission drift was unlikely. Therefore, via its Gold Standard programme, Cafédirect had been able to divert $60 \%$ of its operating profit to PSandD over the previous 8 years. However, with success came new challenges.

\section{Period 2: Increasing Value Spillover: Differentiating the Business Model}

As early as 2007, the realization emerged that Cafédirect had to change, which was evident in multiple interviews and observations of weekly strategy meetings. Customers increasingly bought fairtrade, but had a little ability to identify Cafédirect as being ".... anything different to supermarket own-brands" when both carried the Fairtrade Mark (Marketing Manager comment in 2008). Sales growth had stagnated, and "new product development had stalled" (CEO interview in 2012). However, producer problems had changed too, and to serve them better Cafédirect had to change.

\section{Challenges and Opportunities}

On the commercial front growth in Fairtrade, coffee and tea markets were all predicted to slow (Mintel 2008). The mainstreaming of fairtrade in the early 2000s had dramatically changed the composition of the fairtrade market, away from social enterprises like Cafédirect, towards a plethora of other organizations using different value chains with varying rationales for fairtrade engagement (see Doherty et al. 2013 for the full history of this). Major brands, and ownlabel supermarket brands, both carrying the Fairtrade Mark, and matching Cafédirect's quality, were becoming widely available, but at vastly lower prices than Cafédirect could achieve whilst maintaining its Gold Standard commitments. The growth of supermarket fairtrade own label, with 63\% of Fairtrade coffee sales, is a particularly notable change at this time (AC Nielson 2015). The hot drinks' category had also seen the rise of other, cheaper, and less stringent sustainability certification labels such as Rainforest Alliance
(Mintel 2013b), which many consumers cannot differentiate from Fairtrade (Davies and Gutsche 2016).

In terms of societal value spillover, however, there were also environmental changes. It was becoming apparent that although, in the short-term, improved income was important to producers, long-term issues related to the environment (particularly climate change) and crop dependence were becoming equally, if not more important. Many of Cafédirect's producers began to suffer the effects of climate change, with one producer commenting at the Cafédirect's producers conference in 2013, "we are battling against coffee leaf rust which has intensified due to changing climatic conditions" (a fungal infection which kills coffee plants) and soil quality (which was reduced due to poor rainfall and high winds). Cafédirect, therefore, had the opportunity to expand its work with producers to include climate change adaption and crop diversification. The impact of the decisions to create new types of societal value led Cafédirect to adapt its value creating activities, which manifested in a distinct change in the business model.

\section{The Business Model}

In terms of value spillover, Cafédirect from 2006 onwards had been engaged in exploring climate change adaption. They partnered with German carbon emissions company GTZ to look at ways of reducing emissions in their supply chain, and offsetting those they could not reduce to become zero carbon (Cafédirect Plc. 2010). With growers, they had invested profits from commercial activities into connecting producers via mobile phone discussion forums, to share information on climate change adaption (presentation at the AGM in 2012), and they also helped farmers to plant new coffee plants to replace those blighted by coffee rust (Cafédirect Plc. 2009). There was, therefore, a gradual but insistent shift from Cafédirect as a fairtrade brand to Cafédirect the sustainable coffee and producer advocacy company. With this, we observed an increased differentiation of activities, with the purely commercial focus on Cafédirect giving way to a mixture of activities related to climate change, which competed for leadership time and organizational resources.

To deal with the challenge of greater competition, and to explain the diversified work with growers, Cafédirect believed that it needed to "rejuvenate its brand" (CEO at the AGM in 2009). One rationale for this redesign stemmed from the belief within Cafédirect that its brand was too closely associated with the Fairtrade Mark, which was no longer representative of the value spillover achieved, and according to one informant in 2009:

Cafédirect had allowed itself and its brand to be defined as Fairtrade and then when everybody else comes along and offers the same benefits and the same 


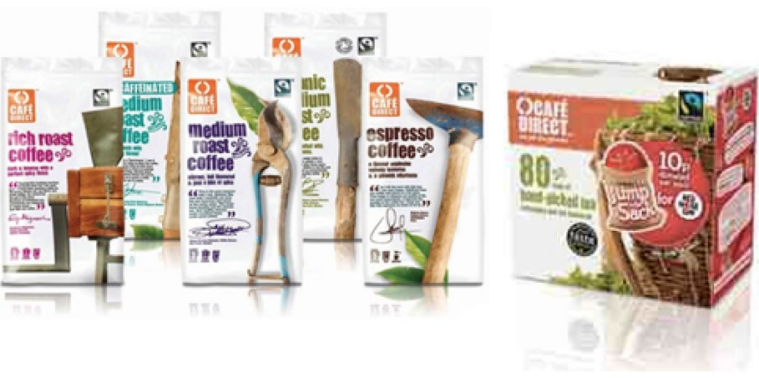

Fig. 5 Provenance rebrand image

story but with cheaper prices. Then the consumer is going to think if all that brand stands for is Fairtrade and I can buy that 50pence or a $£ 1$ cheaper! Why am I spending extra money?

The company set out on an exercise to target their customers with a stronger social message that would appeal to the ethics of their customers. The first phase was to identity who was buying Cafédirect. The analysis suggested two core customer segments that the company termed dark green and light green: dark greens going out of their way to buy ethically/environmentally, and light greens open to the idea but potentially not purchasing so frequently. As such, they had a core market of existing customers and some potential growth into new customers. Focus groups were then used with participants selected from both segments to shape the brand image and message.

Following this, the packaging was redesigned to show authentic tools used by growers to tend their crops (see Fig. 5). According to the CEO of Cafédirect in 2009:

The aim was to show our point of difference by capturing the pride and passion of the growers and to demonstrate our special connection between smallholder craftsmanship and taste.

The key message of the rebrand was on what was unique about Cafédirect (i.e., farmer owned, being a sustainability pioneer, having close relationships with farmers). However, for many of the employees at Cafédirect, this left an unresolved issue for an authentic branding exercise - they needed to deal directly and "live up to their name" (CEO in 2014). To be authentic, Cafédirect decided to go the extra mile and shorten their supply chain, developing a new business model, as depicted in Fig. 6.

For 13 years, sales broker Bridgethorne had represented Cafédirect in the UK supermarket sector, and in April 2009, their contract was terminated bringing sales in-house. Bridgethorne were viewed by supermarket retailers as one of the best sales brokers in that sector. One key informant from the supermarket sector said in 2010:

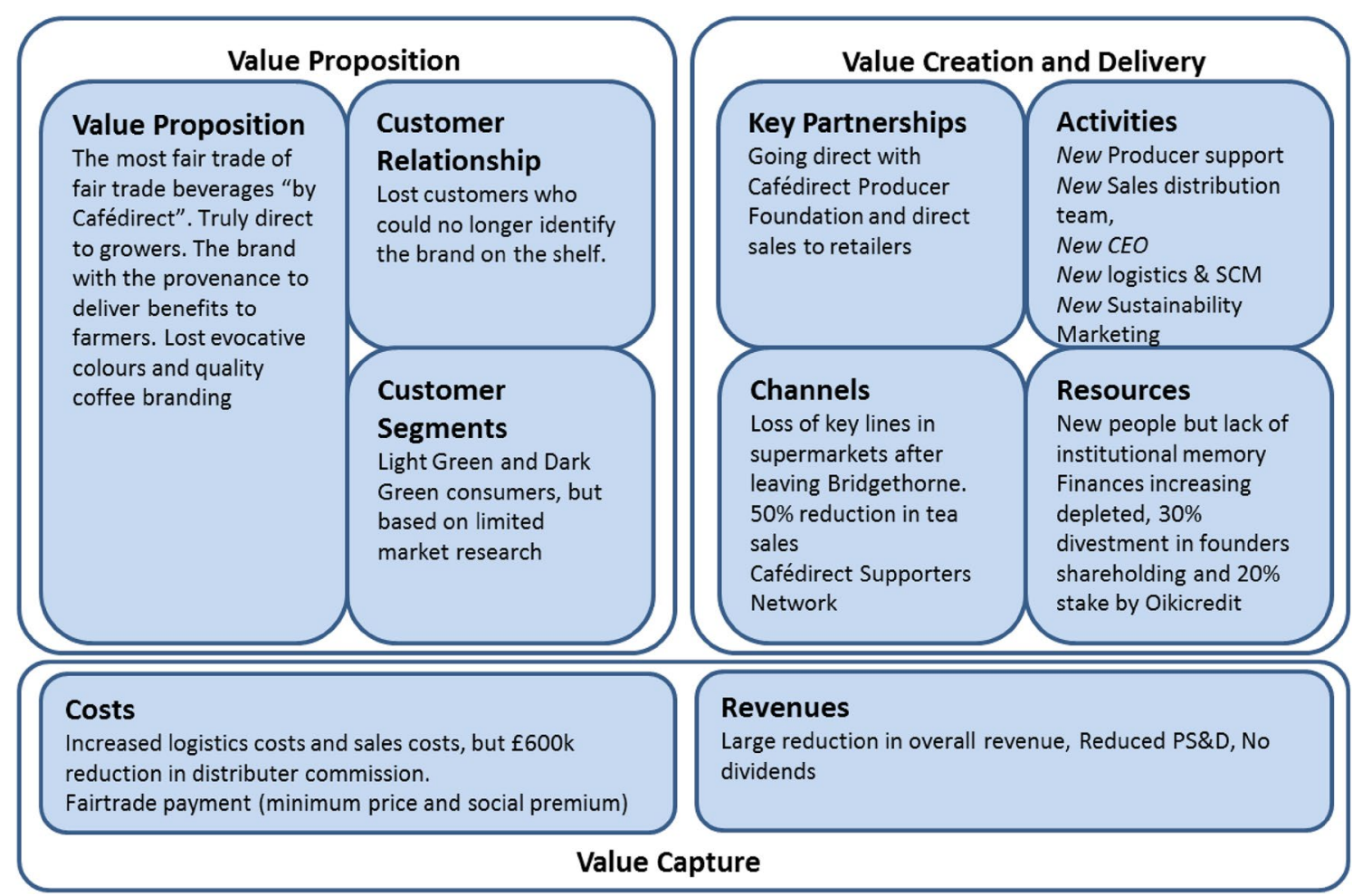

Fig. 6 Cafédirect business model period 2 


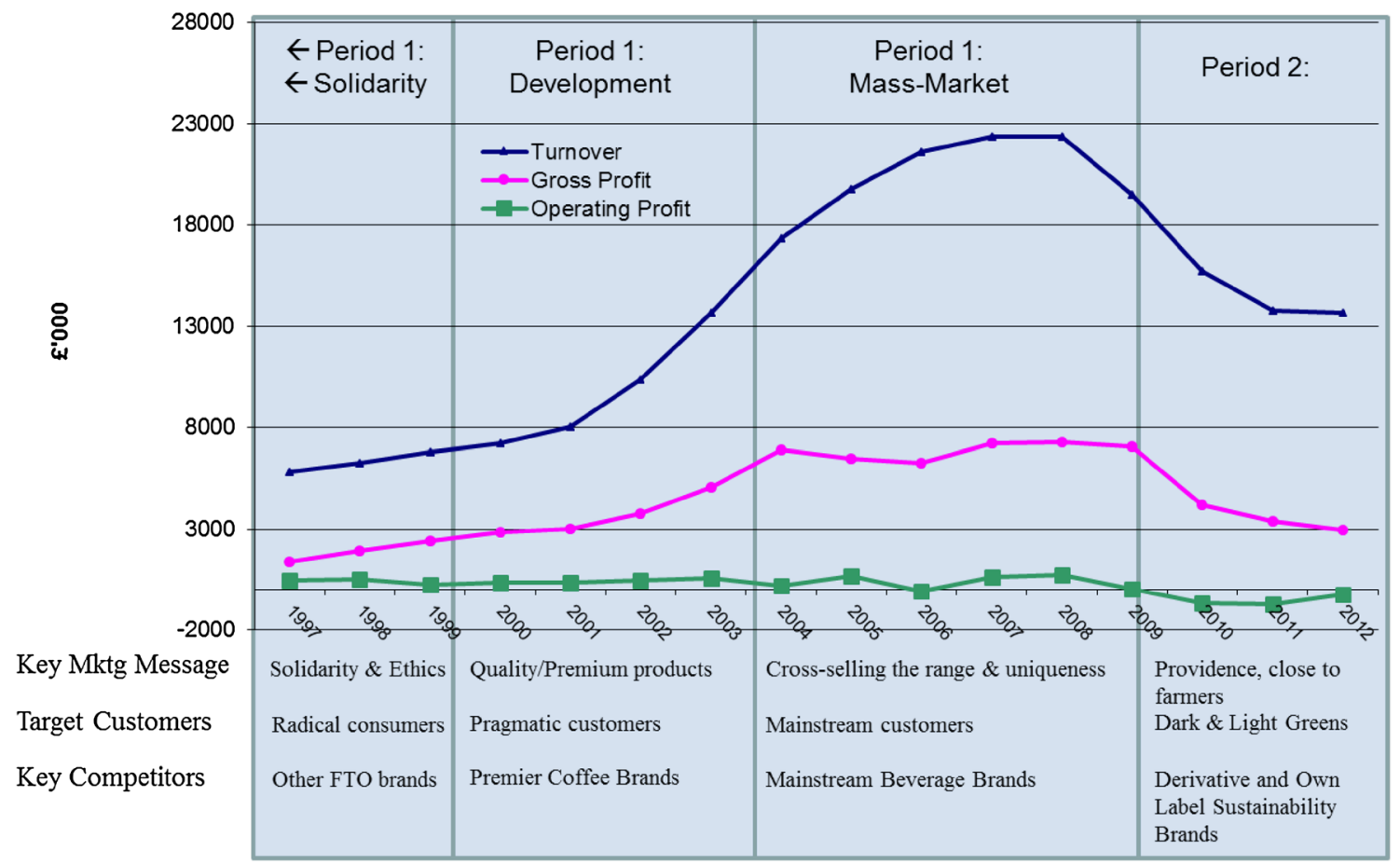

Fig. 7 Catastrophe at Cafédirect

We have a very good working relationship with Bridgethorne and they were very knowledgeable about the hot beverage sector. We miss that level of expertise

In addition, since the inception of Cafédirect, Twin Trading had both purchased the coffee for Cafédirect, and managed the PSandD. One senior manager explains in 2012:

At one point in the business [Cafédirect] nobody picked-up the phone to talk to a supermarket or a producer group. Now we had decided to live up to our name and go direct.

In 2009, Cafédirect brought PSandD in-house. This brought the previous value spillover that was contingent on Twin Trading, in-house, and as such became automatic spillover-and needed new processes, mechanisms, and people to achieve it. Three new staff members were, therefore, brought in to manage supply chain, product quality, and producer relationships, respectively. This all followed on the back of replacing the former CEO (a long-time social activist and leader in social enterprise) with a former fast moving consumer goods Marketing Director. With increasing responsibility for creating automatic value spillover in relation to PSandD, plus newer contingent value spillover on climate change and supply-chain sustainability, the wholemanagement structure changed. The new CEO's lack of experience in sustainability issues was managed through the creation of a new middle-management post of Head of Impact and Sustainability. They also hired three retail sales executives to replace Bridgethorne. As shown in our depiction of the business model in Fig. 6, Cafédirect became more complex, covering an array of differentiated economic, social, and environmental activities, with both automatic and contingent value spillover.

\section{The Results}

These changes meant that Cafédirect had reduced its cost base. Bringing the sales operation in-house saved the company " $£ 600 \mathrm{k}$ in sales commission in the first 12 months" alone (Logistics Manager interviewed in 2012). Cafédirect, therefore, remained strong in terms of net assets, which were $£ 12 \mathrm{~m}$, and also had cash in the bank of $£ 4 \mathrm{~m}$ at the end of 2009 (Cafédirect Plc. 2010). The removal of Bridgethorne also allowed Cafédirect to go directly to retailers with the companies story, something multiple interviewees suggested Bridgethorne struggled to do.

At face value, these decisions to change organizational activities appear logical. However, the decisions taken in combination proved to be an unmitigated disaster (see Fig. 7). The company's turnover declined from $£ 23 \mathrm{~m}$ in the year to December 2008 to $£ 15.7 \mathrm{~m}$ for the year to December 2010, a reduction of 35\% (Cafédirect Plc 2011). A key moment appears to be June 2009 ( 1 month after the rebrand), when monthly sales dropped by $£ 500 \mathrm{k}$ from the previous month (Cafédirect monthly sales ledger, June 2009). 
What occurred was a significant shift in the business model from one in which the societal and commercial logics were integrated, leading to contingent value spillovers in PSandD; to a far more complex social impact driven business model involving direct sales, logistics, supply management, environmental, PSandD, etc. In doing so, the organizations social and environmental value capture moved from a simple contingent model of donating money through trading and profit sharing, to actively managing automatic value spillover in terms of PSandD, plus contingent approaches to environmental management with partner organizations in climate change adaptation and crop diversity. This brought many hybrid tensions to the forefront of the organization, but we will focus on the six crucial tensions which we identified through our analysis, which had both unbalanced the integrated nature of the previous business model and impacted on the hybrid organizing dimensions (Battilana and Lee 2014).

(1) Workforce Composition Tensions With all the changes, we observed that no member of the marketing or senior management team from a previous rebrand in 2004 was still at the enterprise in 2009. Most of the marketing and sales team had come from corporate FMCG companies, as had the new CEO that joined in 2008, with limited knowledge of how to market a brand's ethics authentically (Shareholder comment at Cafédirect, AGM 2012). We interpret from our observations that Cafédirect had difficulty integrating an explicit, core social impact message in the value proposition. This message had been implicit through certification, and secondary to the luxury and quality messaging during the 2000s, when the company was governed by an experienced social enterprise leader. With the new leadership and marketing team, the lack of experience in branding a social enterprise was largely lacking, and we suggest that the heavy focus on sustainability as the core message may have expedited a decline in the brand attractiveness to consumers. The evidence from discussions which we observed and commentary by interviewees who participated in the process was that there was simply an overestimation of the power of ethical messaging in consumer markets.

(2) Customer Communication Tensions Although estimates vary, Vermeir and Verbeke (2006) synthesize that approximately $30 \%$ of consumers have a positive attitude towards ethical consumption. This $30 \%$ would, therefore, fall in either the light green or dark green category targeted by Cafédirect. However, evidence shows that an ethical attitude does not always translate into buying behavior (Devinney et al. 2010). In Cowe and Williams's (2000) much cited study, they name the $30: 3$ phenomena where the $30 \%$ of consumers high- lighting ethical consumption attitudes lead to only $3 \%$ ethical purchases. Therefore, Cafédirect who, in 2007, held a $14 \%$ market share in roast and ground coffee were already extended well beyond the true dark and light green market space of people willing to purchase on ethical messaging alone. The movement from the more egocentric, luxury coffee consumption message, with implied ethics, to a more altruistic ethics dominant message created a tension between customer expectations, and organizational offerings. As one employee reflected in 2013: "First and foremost people buy that category to satisfy a need and that's great quality coffee", we would suggest that the workforces' over-compensation for their lack of social enterprise experience caused them to overlook this point. The sales collapse is, therefore, consistent with Obermiller et al.'s (2009) study, suggesting that smaller fairtrade brands need to focus primarily on quality-based value propositions, with ethical appeal secondary.

(3) Value Proposition Tensions The Commercial Director also discussed (2012) how in focus groups you have time to explain the rationale behind packaging ideas:

You can explain the idea of tools and explain why you are doing it, you can explain that those tools are used to craft that coffee and you can talk about the care and attention that has gone into growing the coffee.

However, purchasing decisions for products such as fairtrade coffee are low cognition and habitual (Davies and Gutsche 2016). The complex back-story behind the packaging cannot be conveyed. Sales results suggest that Cafédirect got this value proposition balance wrong.

(4) Branding Tensions The changes in both brand names and colors simultaneously resulted in consumers finding it difficult to locate the new packs in the supermarket. One Cafédirect supporter commented in 2012:

I have been buying Teadirect for years and I just could not find the new product on the shelf, the product was in the store but the white pack color makes it so difficult to see even to the trained eye.

The new tools packaging design also proved unpopular with new employees at Cafédirect, one informant divulges in 2013;

People just couldn't relate to a pair of secateurs on the pack to great tasting coffee and in fact slightly the opposite, as rusty implements on the pack does not communicate a positive view. 
Or even worse, "the only word I can think of is tools that look like instruments of torture" (Marketing Executive in 2013). Both interviewees' reflections and our own interpretation suggest that the company got the branding wrong. The flaws in this redesign created the situation where consumers had to reappraise what brands they bought, as the quote above identifies. This is particularly critical in hot drinks such as tea, as tea brand choice is largely driven by habit, with $55 \%$ of the UK population buying the same brand of tea all of the time (Mintel 2013b).

(5) Channel Management Tensions The failure of the brand to maintain a strong identity was compounded by the change in retailer relations. Poor sales performance combined with the lack of personal relationships via Bridgethorne (interviews with supermarket buyers 2013), led to a 50\% decline in sales of Cafédirect tea (informal discussion with the Logistics Manager in 2012). The supermarkets were not convinced by the new social impact messaging (interviews with supermarket buyers 2013) and although, in the long term, the removal of Bridgethorne might lead to the development of better relationships; Cafédirect lost all the social capital Bridgethorne that had with retailers.

(6) Commercial Focus Tensions During the 1990s, Cafédirect was recognized for being innovative in the premium coffee sector with its Roast and Ground range. However, between 2004 and 2011, product innovation stagnated. This was compounded by increasing NPD activity from its competitors (Mintel 2013a). By the end of the financial year to December 2011, Cafédirect's revenue was down to nearly $50 \%$ compared to the financial year to December 2008 (see Fig. 7). Gross margin also declined to $21 \%$ in the financial year to December 2011, from 29\% in the year to December 2008 and Cafédirect recorded operating losses of $£ 640 \mathrm{k}$ and $£ 700 \mathrm{k}$ in the years to December 2010 and 2011, respectively (Cafédirect 2014). This was exacerbated by a continued loss of retail distribution. According to one senior manager "Cafédirect lost $40 \%$ of its distribution points by the end of 2011". This poor performance led to a number of changes in 2012 including: a new CEO and chair both with hybridity management experience, combined with three departures at board level, and a new commercial director, with a significant experience in the FMCG sector (Cafédirect 2013; Annual meeting observation 2013). The new team took the decision to restructure the remaining business to manage the decline.

\section{Period 3: Structural Separation of Value Creating Activities}

Following the catastrophic impacts of the unbalanced period 2 business model, the very existence of Cafédirect was threatened. By the end of 2012, sales volumes had halved, and turnover reduced to $£ 13.68$ million, they had made an operating loss for 4 consecutive years, purchase volumes from producers had fallen over $60 \%$, social premium and profit sharing more than halved (Cafédirect 2013b). Therefore, across the board, the attempt to increase value spillover had backfired, with reduced commercial, social, and environmental value capture.

\section{Challenges and Opportunities}

The misalignment in the business model represented in Fig. 6 during 2009-2010, with too much focus on the social and environmental value creation, needed addressing to ensure survival. Cafédirect aimed to maintain producer support and work on climate change adaption, but with sales volumes halving since 2009 , this put the company under immense strain. Cafédirect entered its decline in 2009 in a fairly healthy financial position. This gave the company a good buffer. However, by the end of 2015, cash reserves were less than $£ 0.3 \mathrm{~m}$ and current assets down to $£ 3.7$ from $£ 12 \mathrm{~m}$ (Cafédirect 2015). In 2009, Cafédirect donated $£ 700 \mathrm{k}$ to PSandD, over and above their Fairtrade premiums, despite barely breaking even (Cafédirect 2010). However, this was forced to be reduced year-on-year to only $£ 188 \mathrm{k}$ in 2014 and 2015 (Cafédirect 2015). Furthermore, a reduction in purchased raw material volumes from 4000 tons during 2008, to only 1276 tons during 2014, saw total fairtrade premiums fall from $£ 886$ to $£ 352 \mathrm{k}$ (Cafédirect 2015).

One area where being a hybrid caused distinct problems for Cafédirect throughout the years of observation is that they are ultimately in business to help support the farming community, rather than just making money. This should counterbalance in fairtrade organizations, because there should be a high level of integration between social and commercial activities. However, Cafédirect had lost this balance, as the CEO explained in 2014:

We need to craft the balance between the commercial and social objectives and we have [had to] become more entrepreneurial over the past 2 years.

For a commercial enterprise, reducing income can (to a certain extent) be offset by switching suppliers, and certainly reducing charitable donations. In Cafédirect's case, this was not possible. The growers owned $5.5 \%$ of the business by 2014. Furthermore, a commitment to their Gold Standard included agreeing long-term supply contracts and profit sharing. Breaking these would undermine the company's 


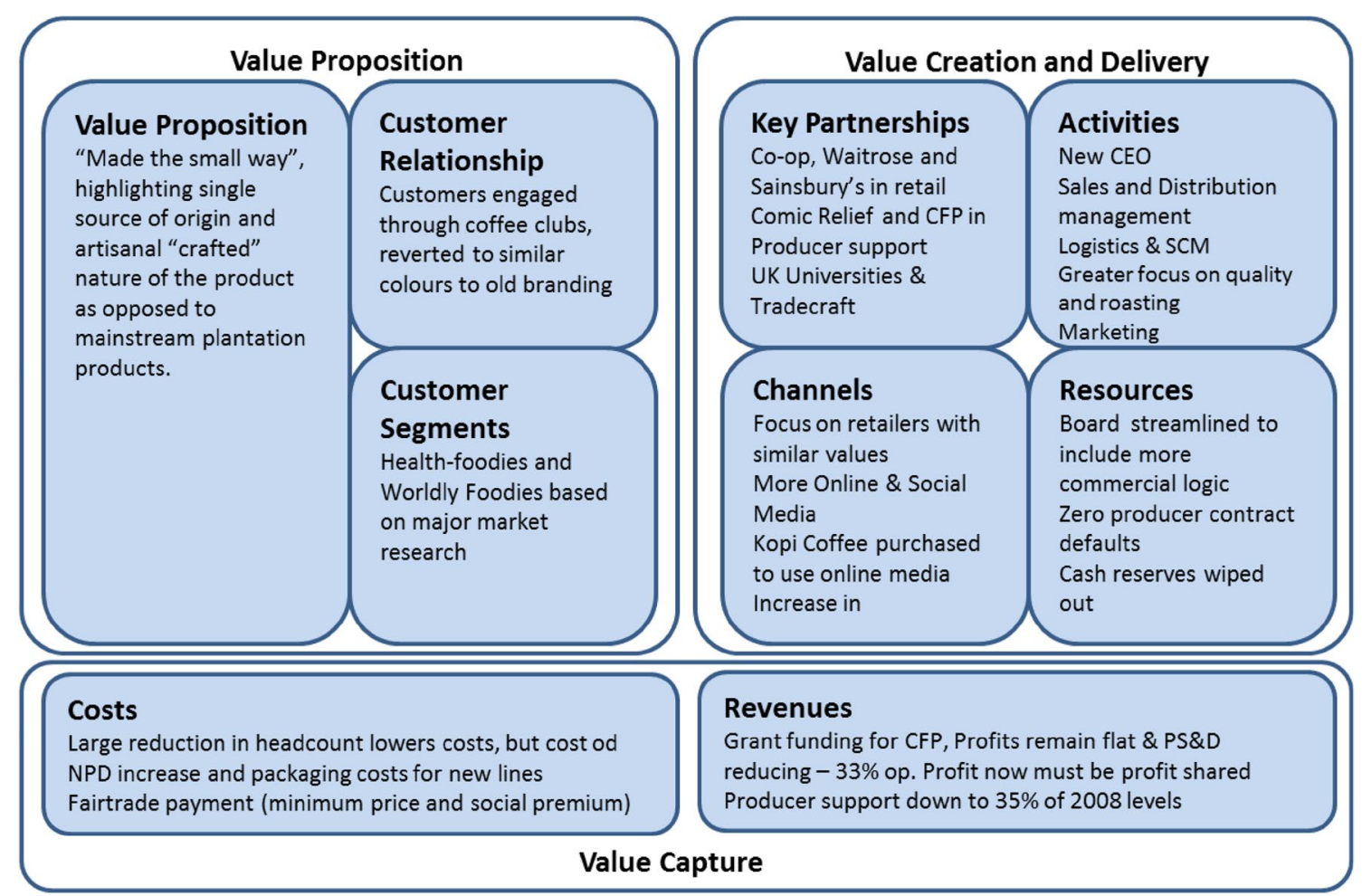

Fig. 8 Cafédirect business model phase 3

social mission. However, by 2012, the company had to make a key decision: risk further decline, or change strategy and try to rebuild the brand with increased focus on their commercial objectives.

Despite increased competitive pressures, Cafédirect were able to maintain strong relationships with growers. Coffee producers were under enormous strain due to climate change problems, including increases in pestilence, and failures of annual frosts which are necessary for high yield (interview with commercial manager from KNCU coffee cooperative in Tanzania 2014; Cressey 2013). This led to a constrained supply across the coffee market with increased competition for raw material supply. A Cafédirect producer speaking in 2014 explains:

MNCs are not just sitting in their headquarters anymore they are sitting in the local villages with their agents and traders trying to source every little grain of coffee and trying to convince our coops to sell outside their cooperatives to them.

Cafédirect has always been a small customer for producer cooperatives, so it would be easy to withdraw supply from, but Cafédirect has experienced "zero defaults on supply" (interview with the Supply Chain Manager 2014). The work with producers on aspects such as climate change adaptation built goodwill with growers. However, poor financial performance led to issues with both the ability to continue supporting producer initiatives, and maintain purchase levels from these loyal suppliers. Many, therefore, sought other sources of income, such as through Organic and Rainforest Alliance certification (Interview with the Supply Chain Manager in 2014).

\section{The Business Model}

As Cafédirect moved into this new era, they had to face up to the hybrid tensions. We identify four major strategic decisions which reshaped the business model between late 2011 and 2013: reintegrating organizational activities and restructuring, a commercial rebrand, refocusing on new product development, and augmenting the business model to ensure that it continued to provide impact for growers (see Fig. 8 for our interpretation of this business model period).

(1) Reintegrating Activities and Restructuring In 2011, significant changes took place with the founding members divesting their $£ 2.7 \mathrm{~m}, 40 \%$ shareholding in Cafédirect down to $10 \%$, and keeping only one position on the board (Cafédirect Plc. 2012). At the same time, the cooperative financial institution Oikocredit increased their shareholding in Cafédirect from 11 to $20 \%$, with consumers buying the remainder of the divested shares, plus a further share issue to increase cash flow (Cafédirect Plc. 2012). The golden share which gave founder 
members veto rights over 56 articles of association was passed on to the Board, giving them power to change their principles, if necessary, to save the company.

Cafédirect also revised their mission in 2013, by moving away from explicitly tying the mission to Fairtrade certification, and showed its preferred identity as a sustainable enterprise, which (as of writing) included Fairtrade certification in practice, but not in the articles of association:

\section{"A rebalanced world which celebrates business as a force for good and measures success in the shared well-being of the communities it touches... Beyond Sustainability by; securing access to resources and opportunities for true well-being for future generations." Cafédirect's New Mission}

The producer's $5.5 \%$ equity was now constituted as the charitable foundation: Cafédirect Producers Foundation (CPF), and was managed totally independently of the company. The structurally separated CPF became entrusted with managing the PSandD funds (donations from Cafédirect), and governed by a chair and three producer directors, who also sit on Cafédirect's Board (presentation by the Chair of the CFP at the AGM in 2012). The CPF; due to its charitable legal status, can also raise additional funds to go with the Cafédirect donations. They raised two 4 year programme grants from UK charity Comic Relief of $£ 600,600$ each for climate change adaptation works in 2012 utilizing this freedom. From this change in governance structure, CPF can function effectively without Cafédirect donations, thus guaranteeing ongoing social impact. However, a constitutional change in 2011 also committed Cafédirect to provisioning $33 \%$ of operating profit to $\mathrm{CPF}$ regardless of their net financial performance (CEO statement at the AGM in 2012). This had the effect of simplifying Cafédirect's business model to focusing on commercial value creation, for onward donation of PSandD money to a legally separate third party (CFP). Value spillover, therefore, reverted to a contingent model for PSandD-related activities, as it did before 2009.

Further revenue decline in 2012 and 2013 led to a strategic review, resulting in a limited restructuring, with five redundancies in early 2014 (e-mail exchanges with the CEO prior to the 2015 AGM). This included the Head of Impact and Sustainability. Impact and Sustainability were now led by the CEO, with Gold Standard Key Performance Indicators included in every employee's objectives, and with social and environmental spillover reviewed quarterly alongside financial measures. The CEO explained in an interview in 2015 that, by integrating the responsibility for sustainability, rather than having it operate through a different set of activities, the company's commercial value creation became linked to the sustainability agenda.

(2) A Commercial Rebrand Cafédirect had "18 years of equity in the pre-2009 product designs" (Commercial Director in 2012), so they researched what consumers valued in their original designs following the failure of the authentic tools branding. This revealed a strong preference for both the rich evocative packaging colors, and also the orange strip, which, according to the research, made the packs recognizable on the retail shelf (interview with Commercial Director in 2012). This new consumer research involved an independent attitudinal segmentation study, using data from the Target Group Index survey (TGI data) ${ }^{1}$. This study segmented hot drinks' consumers who have a range of ethical beliefs, who are interested in quality, and who are not highly price sensitive (Cafédirect Segmentation Booklet 2013). This research identified six groups totaling $9.4 \mathrm{~m} \mathrm{UK}$ hot drinks' consumers and two priority groups to form Cafédirect's new target audience. These two segments were termed worldly foodies (affluent urban professionals driven by a love of quality food and provenance and ethics- $1.7 \mathrm{~m}$ people), and healthy foodies (primarily female, love cooking, and have a healthy lifestyle with strong ethical beliefs and an interest in provenance- $1.8 \mathrm{~m}$ people). These segments were identified by the research as heavy users of roast and ground coffee, with foodie and ethical values. The Cafédirect penetration within these two groups was only 13\%, equivalent to 440,000 shoppers in June 2013 (Cafédirect Segmentation Booklet 2013).

Cafédirect investigated these new target groups, including those people who did and did not buy Cafédirect. The research showed that Cafédirect met their taste and quality requirements, and also identified the differentiating elements of the Cafédirect brand. These included the small-holder focus, direct trading, and the investment of profits in small-holder communities (Cafédirect Segmentation Booklet 2013). These became the three pillars of Cafédirect's differentiated brand positioning, brought together in a communication message titled 'made the small way' (see the packaging in Fig. 9). An explanation of the pillars was included on the back of the packs, stating what Cafédirect means in terms of working with small-holder producers, the text reads 'these small-holders have lived on the land

\footnotetext{
1 Target Group Index (TGI) survey is the longest established single source marketing and media survey in Britain and was established by the British Market Research Bureaux in 1969
} 


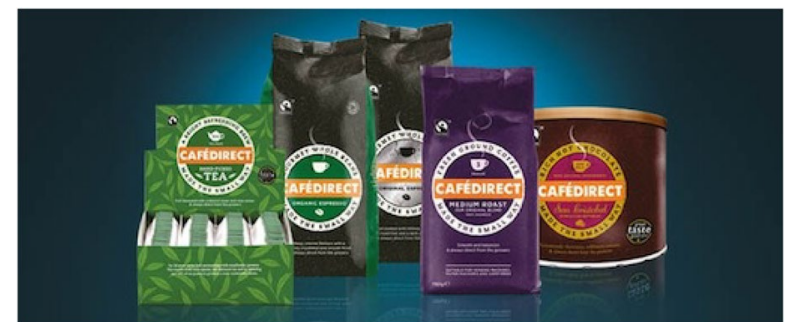

Fig. 9 Made the small way rebrand

for some time, they've got more pride and passion in their coffee, there is more craft that goes into the crop; therefore, you get a better tasting coffee and the benefits go to the grower directly to reinvest in a better future'. Therefore, according to a Marketing Manager at Cafédirect in 2013:

We are now trying to say what's in it for you the consumer and provide an insight for those types of consumers who believe that things that are made better taste better.

In contrast to the authentic tools rebrand, this showed Cafédirect attempting to bring together the interrelated hybrid dimensions of both quality and social positioning, rather than being purely focused on producer value creation. One of the challenges, however, was communicating this differentiation with a limited marketing budget. Cafédirect had been forced to cut their consumer marketing spend to less than $£ 0.7 \mathrm{~m}$ in 2014 compared to the $£ 4 \mathrm{~m}$ spent in 2006 (Cafédirect 2015). In 2015, they took the decision to raise this spend to $£ 1.1 \mathrm{~m}$. To manage this, Cafédirect developed its social media presence, growing its followers and launching an online advertisement.

(3) New Product Development Cafédirect's more in-depth understanding of its target consumer allowed them to be more consumer focused; creating products and communications that spoke to a more tightly defined target audience (field observations, and multiple customer and retailer interviews). A problem repeatedly emphasized by many interviewees, both inside and outside Cafédirect, was a realization that NPD had previously been driven by the support for producers, rather than what the market demands. One senior manager at Cafédirect in 2015 explained:

The passion for the roots of Cafédirect are still here, but the commercial focus is becoming stronger, as everybody is desperate to get the company growing again to prove the model works.
This illustrates the challenge of managing the hybridity within social mission companies, and the need to maintain a balance between the commercial and social logics. The 'made the small way' campaign is an example of product positioning, where social and environmental criteria are integral to the quality dimension. This is supported by Cafédirect data, showing that $18 \%$ of their total sales come from one of their single origin coffees, Machu Picchu (Cafédirect Sales Ledger 2014). NPD for 2013 included a new single origin Costa Rican roast and ground coffee. For 2015, they also developed a premium instant coffee, coffee pod products, and a single origin black blended tea range.

(4) Augmenting the Cafédirect Business Model: Cafédirect departed from its normal organic growth on June 1st 2014 by purchasing a new coffee club business called Kopi coffee (e-mail exchange with CEO in 2014). This e-commerce business dealt directly with consumers via home delivery of single origin specialty coffee, improving the relationship with consumers beyond the supermarket retail environment, and allowed Cafédirect to strengthening value creation and delivery (interview with the Commercial Director in 2015). This facilitated Cafédirect trading as directly as possible, as explained by the CEO in 2015:

[Kopi Coffee] gets our connection with growers and drinkers to be much closer and have much more dialogue, and it offers alternative and highvalue, and I think the supply chain is more in our control than I think the multiple grocers.

After trading in 2014/15 under the Kopi brand, this online business has now been rebranded as Handpicked by Cafédirect with sales growing at over $100 \%$ per year.

Furthermore, Cafédirect commenced going direct to business customers such as the Royal Albert Hall and Glastonbury Festival. Cafédirect was nominated through a tender process to be a preferred direct supplier of UK Universities (interview with the Commercial Director in 2015). Cafédirect also made some important choices with regard to retail partnerships, deciding to align itself with those retailers which share some of the same values such as Cooperative Food, and Sainsbury's and Waitrose Supermarkets. It also rebuilt its commercial partnership with fairtrade pioneer Traidcraft going from $£ 300 \mathrm{k}$ to over $£ 500 \mathrm{k}$ sales (interview with the CEO 2016).

Cafédirect also developed new markets, particularly the 'out of home' hot beverage food service sector, which was worth $£ 3 \mathrm{bn}$ in UK, with a growth of $8.1 \%$ since 2006 (interview with food service sales manager 
2015). Cafédirect refocused on both the food service wholesalers and the end user in this sector, e.g., the Emirates football stadium (interview with the CEO in 2016).

\section{The Result}

Signs of recovery began in 2015 (see Fig. 10) with Cafédirect roast and ground coffee sales up by $22 \%$, overall coffee sales were up $14 \%$, and hot chocolate up by $16 \%$ (AC Nielson 2015). In contrast, Cafédirect instant coffee was down $2 \%$. Furthermore, Cafédirect's core business of roast and ground coffee has outperformed a number of its competitors for the first time since the early 2000's (AC Nielson 2015). However, the double digit growth of roast and ground coffee was counterbalanced by Cafédirect losing 11 distribution points in Tesco supermarket due to a price-driven range review (interview with Cafédirect's supply-chain manager at the 2015 AGM). In contrast, Cafédirect sales at Waitrose supermarkets were up over $10 \%$ in 2015 and 2016 on the back of a joint Cafédirect-Waitrose cinema advertising campaign in 2014 (interview with CEO 2016). Nevertheless, despite a tea recovery plan, Cafédirect sales of tea continued to decline. Tea as a whole market was down by $-3.7 \%$ in volume and $-6.1 \%$ in value, with Cafédirect tea down $15 \%$ in 2016, but some areas of the tea market are growing, e.g., specialty teas, which Cafédirect aim to move into (interview with CEO 2016).

\section{Discussion and Conclusions}

There is an increasing acceptance that managing social enterprises is problematic due to the sometimes conflicting organizational purposes (Austin et al. 2006; Pache and Santos 2013; Smith et al. 2013). The literature on hybrid tensions in social enterprises is, however, in its infancy (Doherty et al. 2014), with a few papers exploring how these tensions manifest in the social enterprises, or how they are managed (Frumkin and Andre-Clark 2000; Phillips et al. 2011; Teasdale 2012). By investigating hybrid tensions longitudinally, through the evolutions of Cafédirect's business model, we identify some causes of intensification of hybrid tensions, such as changing the balance of value capture objectives, diversifying the value creation activities undertaken, and changing the customer value proposition. We also explore the means by which this single case attempted to increase multiple forms of value in a more integrated and balanced way, and alleviate some of these tensions (albeit not always successfully).

Cafédirect provides a clear example of a social enterprise that felt tensions in trying to balance its commercial objectives and addressing changes in its intended environmental and societal value capture. Consequently, they made changes to include new forms of financial support for growers, as well as dealing with issues of climate change, and climate change adaption, which they were not doing before 2008. In particular, the level of automatic value spillover (Santos et al. 2015) they were actively managing changed

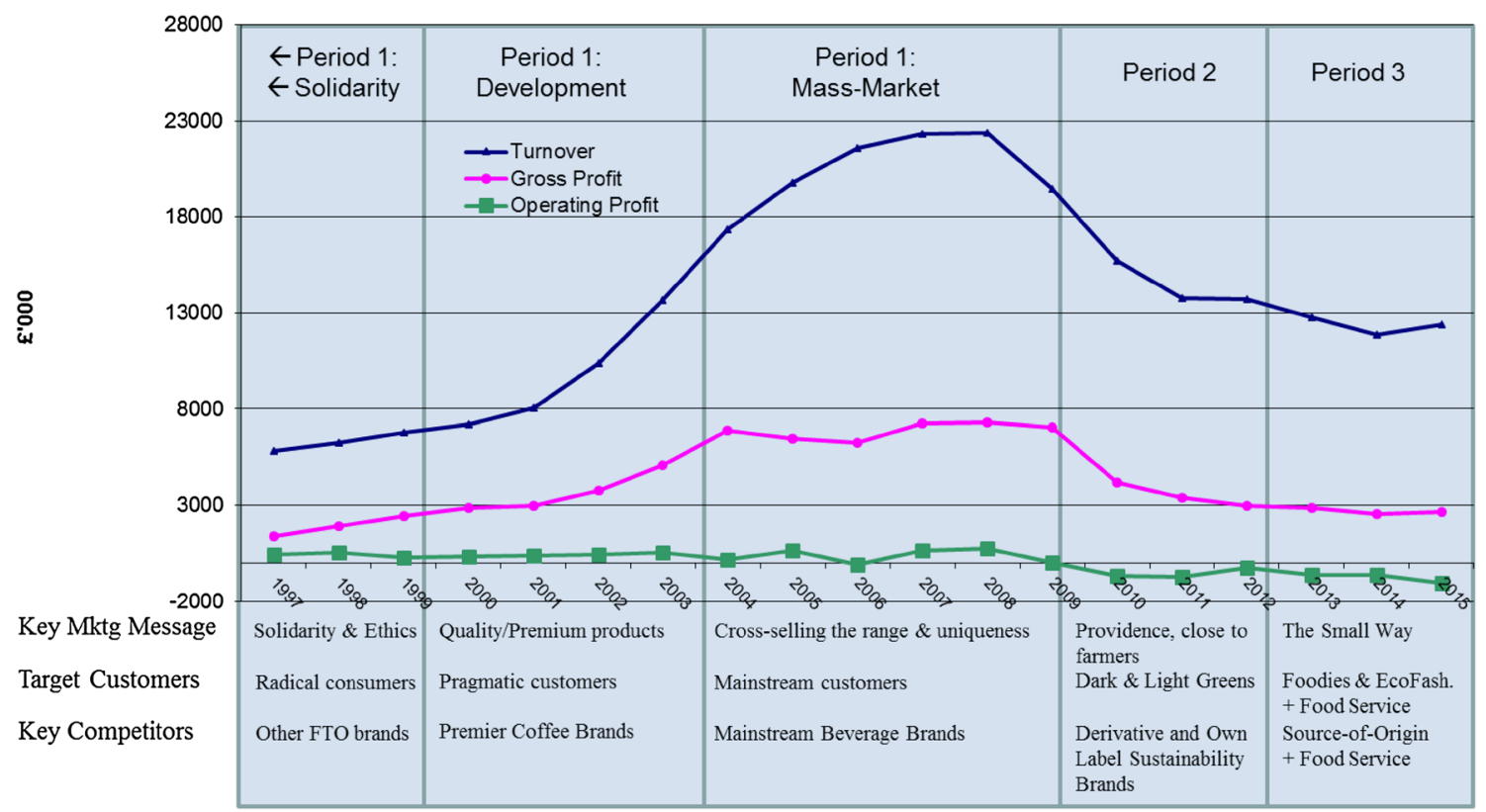

Fig. 10 Cafédirect business performance 1997-2015 
through period 2 increased markedly. In doing so, Cafédirect appeared to priorities social and environmental objectives over commercial objectives, creating a different balance to the organization from both its earlier and later business models. Ultimately, they attempted to make organizational changes reflected in every box of their business model canvas (see Figs. 3, 6, 8), and appear (in our interpretation) to make the whole organization more complex, with more differentiated activities focused on different value capture objectives, which made it far more open to hybrid tensions. The competition between these activities for management time and organizational resources led to a lack of clear direction, and a lack of focus on the commercial aspects of the enterprise, leading to an ultimate reduction in all forms of value capture.

The core theoretical contribution of this paper is in linking the fields of hybrid organizing and sustainable business models, and the implications for each in terms of their ongoing theoretical development in explicating hybrid organizations. In their seminal paper, Battilana and Lee (2014) identify five dimensions upon which organizations must manage their hybridity: (1) organizational activities, (2) workforce composition, (3) organizational design, (4) culture, and (5) inter-organizational relationships. Rather than separating these out as independently manageable, the field of sustainable business models provides the opportunity to view these as part of an integrated approach, leading to multiple types of value capture. Taking this broader view, we are able to identify the interlinkage between these aspects, and posit that changing the level of integration or differentiation in any of these areas will have knock-on effects to the rest of the business model, potentially leading to destabilization as seen in Cafédirect.

By refocusing attention on the types of value spillover (Santos et al. 2015), and the value creating activities which lead to this value spillover, rather than Battilana and Lee's (2014) focus on the competing logics, we can better identify where contingent and automatic value spillover will optimize societal value. Santos et al. (2015) focus on the interplay between automatic and contingent value spillover, and the extent to which beneficiaries are the same people as the customers. They propose that where societal value is created automatically, and where clients and beneficiaries are the same people, mission drift, and financial instability, and thus, hybrid tensions are lessened. However, we propose a more nuanced interpretation.

First, organizations often have more than one type of societal value spillover. As we see in Cafédirect, these can be both automatic and contingent on third parties, dependent on the business model in operation (such as in the different states of the PSandD value spillover in periods 1 and 2). Where third parties are required for the capture of contingent value spillover, it does not necessarily infer a higher chance of missions drift as suggested by Santos et al. (2015). Indeed, in the Cafédirect case, the movement to greater automatic spillover in relation to PSandD had the opposite effect due to the differentiation of activities, and, in our interpretation, a lack of the dynamic capabilities in-house to deliver on the new forms of value capture (Eisenhardt and Martin 2000). As such, we propose that if the missions and dynamic capabilities of the third party are synergistic with the value creation activities of the hybrid, contingent spillover allows for greater potential value capture in total, and a reduction in hybrid tensions as each organization focuses on its own area of expertise. Indeed, at Cafédirect, both financial stability and potential for mission drift increased with the move to automatic value spillover due to the differentiation of activities for commercial and societal value creation.

We agree with Santos et al. (2015) that customers also being beneficiaries would reduce hybrid tensions, but mainly because it would be more likely lead to a greater integration of activities. Therefore, as shown in Fig. 2, the level of integration of activities targeting the types of value spillover is of great importance, not just the type of value spillover. We, therefore, propose Fig. 11 to build on the work of Santos et al. (2015), Battilana and Lee (2014), Battilana et al. (2012), and Ebrahim et al. (2014) in identifying the potential inter-relationship between activity integration, types of societal value spillover, and the nature of hybrid tensions. Where automatic spillover is directly captured by the commercial activities, this would present the least likely scenario for hybrid tension, mission drift, and financial instability (lower left-hand quadrant, Fig. 11). In particular, if the societal value is embedded in the product or service offered [e.g., in sustainable entrepreneurship (Davies and Chambers 2018)]. However, contingent value spillover can be just as stable where the third-party dealing with the contingent value

\begin{tabular}{c|l|l|}
\hline $\begin{array}{r}\text { Differentiated } \\
\text { activities }\end{array}$ & $\begin{array}{l}\text { Hybrid tensions are } \\
\text { derived from } \\
\text { superfluous activities } \\
\text { which do not lead to } \\
\text { automatic value } \\
\text { creation, consider } \\
\text { divesting activities. }\end{array}$ & $\begin{array}{l}\text { Hybrid tensions can be } \\
\text { relieved by passing } \\
\text { more activities to } \\
\text { partners with greater } \\
\text { levels of dynamic } \\
\text { capabilities in value } \\
\text { capture space. }\end{array}$ \\
\cline { 2 - 3 } Integrated \\
activities & $\begin{array}{l}\text { Hybrid tensions should } \\
\text { be limited as commercial } \\
\text { value capture and } \\
\text { societal value capture } \\
\text { are derived from the } \\
\text { same activities, and all } \\
\text { are internally controlled. }\end{array}$ & $\begin{array}{l}\text { Hybrid tensions will be } \\
\text { related to the extent of } \\
\text { synergy, and quality of } \\
\text { relationships with } \\
\text { partner organizations. }\end{array}$ \\
\cline { 2 - 3 } & Automatic Value \\
Spill-Over & $\begin{array}{c}\text { Contingent Value } \\
\text { Spill-Over }\end{array}$ \\
\hline
\end{tabular}

Fig. 11 Nature of hybrid tensions in relation to activity differentiation and value spillover 
capture has the requisite dynamic capabilities and mission to achieve it (lower right-hand quadrant, Fig. 11). Hybrid tensions are likely to emerge when commercial and societal value creation activities compete due to differentiation in value creating activities (upper quadrants, Fig. 11). Investigating the sustainable business models of hybrid enterprises, therefore, provides a valuable tool for practitioners to map out potential areas in which differentiation of value creating activities may be present, and how they could be managed as per Fig. 11.

Utilizing the business model canvas based on Bocken et al.'s (2014) refinement: value proposition, value creation and delivery, and value capture, we can extrapolate on the potential sources of hybrid tensions and investigate the implications of this study.

With regard to the value propositions, there is limited extant literature related to hybrid tensions in the marketing of social enterprises. Hahn and Ince (2016) and Moss et al. (2011) explicitly state the need to incorporate hybridity into social enterprise value propositions. However, both Dey and Teasdale (2016) and Davies and Chambers (2018) suggest the opposite that hybrid ventures should tailor messaging to the target audience, not the mission. Our case appears to confirm the later view, social enterprises should focus on producing stakeholder centric messaging. We expand on this in the case by exploring the potential tensions in approaches to customer segmentation, value proposition development, brand messaging, and communication complexity. In each of these areas, we see that shifting the value proposition communications to a more societal impact focus exposed the company to many risks, as the external parties fail to move with the organization. Cafédirect could have actioned many of the strategies targeting societal impact, without communicating them to retailers and consumers. Latterly, a movement back towards commercial communication (even if now in a niche market) has stabilized the sales decline. Therefore, we propose that social enterprises should prioritize customer value creation in their customer facing value proposition, making hybrid/social aspects more implicit (Obermiller et al. 2009). The majority of customers purchase consumer goods for their functional or symbolic meaning, not their ethics (Davies and Gutsche 2016). Creating unnecessary tension through convoluting these messages is problematic for the commercial value capture. We also propose that those customers with strong ethical inclinations will still be satisfied via the more implicit messaging.

With regard to value creation and delivery, ensuring the correct balance of social and commercial skills and experience on the board, partner organizations, and in the commercial delivery team is essential. Cafédirect pursued a staff recruitment strategy of FMCG experience at all organizational levels, leading to a knowledge gap in how to market an ethical brand. They also tried to integrate equivalent skills in retail sales and producer support, pulling away from business partners with a wealth of skills and experience. When Cafédirect faced up to its tensions, this resulted in the departure of the CEO and other board members. By integrating growers onto the board, and adding a Chairperson and new CEO with experience in hybrid type ventures, and reverting to contingent value spillover, a clearer more integrated strategy for dealing with hybrid tensions emerged. The case study highlights the potential danger of overcomplicating the value creating activities in hybrid ventures (Baumgartner 2009). Cafédirect's original model was, in our opinion, relatively simple and well integrated. Creating both automatic (customer education and fairtrade premiums) and contingent (PSandD and profit sharing) value spillover simultaneously with increased sales (thus showing an integrated approach). This reduced both job role uncertainty in the workforce, and allowed the governance mechanisms of the enterprise to focus on societal value capture, whilst the workforce focused on commercial value capture, in particular marketing and branding activities. The automatic value spillover in terms of customer education and pioneering fairtrade involved no differentiation from the commercial activities of marketing and selling more products. However, in period 2, conceptualized in the second business model (see Fig. 6); fewer business partners were engaged in value creation activities, bringing about both an increase, and a differentiation of activities within the organization, with a notable negative effect. In period 3, by reverting, via structural separation, to the previous form of contingent value spillover based on donations to a third party to conduct PSandD (although, in this instance, the third party is a related entity), job role certainty was somewhat improved. In addition, value creating activities were simplified and reintegrated with the new key performance indicator processes. This has then driven forward commercial expansion through new product development, new channels, and an augmented business model, all targeting growing sales long-term.

With regard to value capture; as discussed in Fig. 11, focusing on contingent value spillover is unproblematic if the partner is more capable of achieving that value capture. Cafédirect in 2009 failed to understand the consequences of terminating its alliances with its contingent value capture partners (Twin Trading and Bridgethorne). This resulted in external tensions associated with legitimacy, particularly in the retail sector. Even at its largest Cafédirect was only 39 people, and trying to manage far too many aspects of its triple-bottom-line business model became untenable. By simplifying the business model to allow others to manage value capture in the areas of their expertise, it eases hybrid tensions from day-to-day activities. Active management of partners and governance systems can, therefore, be seen to open up possibilities to new ways of working, which help to promote both commercial and societal value capture. This 
further supports the work of Crucke and Knockaert (2016) who warned of the dangers of fault lines occurring in complex governance structures which were not aligned to the hybrid mission.

The overarching lesson from this case, however, is the danger of not managing a business model with an integrated strategy. Boons and Lüdeke-Freund (2013) explicitly state that business models are designed to manage complex and potentially conflicting goals. The whole field of sustainable business models demonstrates the nature of this integrated approach to managing multiple forms of value capture which sheds new light on the dimensions of hybrid organizing (Baumgartner 2009; Bocken et al. 2016; Rauter et al. 2015). Ironically, this literature draws on social enterprises as archetypal examples of these integrated approaches (Boons and Lüdeke-Freund 2013; Bocken et al. 2014; Grassl 2012), yet the social enterprise literature itself focuses on conflict and tensions (Austin et al. 2006; Battilana and Lee 2014; Smith et al. 2013). By taking a sustainable business model approach, it is possible to identify via a fine-grained analysis of value capture where these tensions may potentially exist, but also helps to identify new hybrid organizing dimensions for alleviating these tensions. By investigating how to make a single integrated business model, as opposed to differentiated models for social, environmental, and economic value creation, it is possible to identify a business model which minimizes hybrid tensions, and facilitates the integrated attainment of multiple forms of value capture.

\section{Compliance with Ethical Standards}

Conflict of interest The first author declares that he has no conflict of interests. The second author owns stock in the case organization, but declares no other conflict of interest.

Ethical Approval All procedures performed in this study involving human participants were in accordance with the ethical standards of the respective institutions' codes of good practice, and codes of ethics. The management of data is compliant with the UK Data Protection Act 1994, the RCUK, the Concordat to Support Research Integrity 2012, and with the 1964 Helsinki declaration and its later amendments. We received informed consent from every participant, including those informally interviewed. All agreed to be named, but the authors took the decision to anonymize their responses in this paper. The company also gave written explicit consent for its name to be used.

Open Access This article is distributed under the terms of the Creative Commons Attribution 4.0 International License (http://creativeco mmons.org/licenses/by/4.0/), which permits unrestricted use, distribution, and reproduction in any medium, provided you give appropriate credit to the original author(s) and the source, provide a link to the Creative Commons license, and indicate if changes were made.

\section{References}

AC Nielson. (2015). Coffee and tea sales last 52 weeks at week ending 15th August 2015. Market Report: AC Nielson.

Arradon, G. (2007). On the borderline: Development trusts tackling poverty in UK. London: The Development Trusts Association.

Askey, H., \& Knight, P. (1999). Interviewing for social scientists. London: Sage Publications.

Austin, J. (2010). The collaboration challenge. How non-profits and businesses succeed though strategic alliances. San Francisco: Jossey Bass.

Austin, J., Stevenson, H., \& Wei-Skillern, J. (2006). Social and commercial entrepreneurship: Same, different or both? Entrepreneurship Theory and Practice, 30(1), 1-22.

Barnes, D. M. (1996). An analysis of the grounded theory method and the concept of culture. Qualitative Health Research, 6, 429-441.

Battilana, J., \& Dorado, S. (2010). Building sustainable hybrid organizations: The case of commercial microfinance organizations. Academy of Management Journal, 53(6), 1419-1440.

Battilana, J., \& Lee, M. (2014). Advancing research on hybrid organizing. The Academy of Management Annals, 8(1), 397-441.

Battilana, J., Lee, M., Walker, J., \& Dorsey, C. (2012). In search of the hybrid ideal. Stanford Social Innovation Review, 10, 51-55.

Baumgartner, R. J. (2009). Organizational culture and leadership: Preconditions for the development of a sustainable corporation. Sustainable Development, 17(2), 102-113.

Baumgartner, R. J., \& Ebner, D. (2010). Corporate sustainability strategies: Sustainability profiles and maturity levels. Sustainable Development, 18(2), 76-89.

Bell, B., \& Haugh, H. (2014). Working for a social enterprise: An exploration of employee rewards and remuneration. In S. Denny \& F. Seddon (Eds.), Social enterprise: Accountability and evaluation around the world (pp. 67-84). London: Routledge.

Besharov, M. (2014). The relational ecology of identification: How organizational identification emerges when individuals hold divergent values. Academy of Management Journal, 57(5), $1485-1512$.

Billis, D. (2010). Hybrid organizations for the third sector. Challenges for practice, theory, and policy. London: Palgrave Macmillan.

Bocken, N. M. P., Fil, A., \& Prabhu, J. (2016). Scaling up social businesses in developing markets. Journal of Cleaner Production, 139, 295-308.

Bocken, N. M. P., Short, S. W., Rana, P., \& Evans, S. (2014). A literature and practice review to develop sustainable business model archetypes. Journal of Cleaner Production, 65, 42-56.

Boons, F., \& Lüdeke-Freund, F. (2013). Business models for sustainable innovation: State-of-the-art and steps towards a research agenda. Journal of Cleaner Production, 45, 9-19.

Brown, W. A., \& Iverson, J. O. (2004). Exploring strategy and board structure in non-profit organizational. Non-profit and Voluntary Sector Quarterly, 33(3), 377-400.

Cafédirect plc. (2004) Annual Report and Accounts 2004, 2003-2004. City Cloisters, London.

Cafédirect plc. (2009). Cafédirect plc Report and financial statements 2008, 2007-2008. London: Baker Tilly International.

Cafédirect plc. (2010). Cafédirect plc Report and financial statements 2009, 2008-2009. London: Baker Tilly International.

Cafédirect plc. (2011). Cafédirect plc Report and financial statements 2010, 2009-2010. London: Baker Tilly International.

Cafédirect plc. (2012). Cafédirect plc Report and financial statements 2011, 2010-2011. London: Baker Tilly International.

Cafédirect plc (2013a). Cafédirect segmentation research booklet, (internal document).

Cafédirect plc. (2013b). Cafédirect plc Report and financial statements 2012, 2011-2012. London: Baker Tilly International. 
Cafédirect Sales Ledger (2014). Sales Ledger, London.

Cafédirect plc. (2015). Cafédirect plc Report and Financial Statements 2014, 2013-2014. London: Baker Tilly International.

Cowe, R., \& Williams, S. (2000). Who are the ethical consumers. Manchester: Co-operative Bank.

Cressey, D. (2013). Coffee rust regains foothold. Nature, 493(7434), 587.

Crucke, S., \& Knockaert, M. (2016). When stakeholder representation leads to faultlines. A study of board service performance in social enterprises. Journal of Management Studies, 53(5), 768-793.

Dacin, P. A., Dacin, M. T., \& Matear, M. (2010). Social entrepreneurship: Why we don't need a new theory and how we move forward from here. Academy of Management Perspectives, 24(3), 37-57.

Davies, I. A., \& Chambers, L. (2018). Integrating hybridity and business model theory in sustainable entrepreneurship. Journal of Cleaner Production, 177, 378-386.

Davies, I. A., Chambers, L., \& Haugh, H. (2018). Barriers to social enterprise growth. Journal of Small Business Management. https ://doi.org/10.1111/jsbm.12429.

Davies, I. A., Doherty, B., \& Knox, S. (2010). The rise and stall of a fair trade pioneer: The Cafédirect story. Journal of Business Ethics, 92(1), 127-147.

Davies, I. A., \& Gutsche, S. (2016). Consumer motivations for mainstream "ethical" consumption. European Journal of Marketing, 50(7/8), 1326-1347.

Dees, J. G., \& Elias, J. (1998). The challenges of combining social and commercial enterprise. University-Business partnerships: An assessment Norman E. Bowie Lanham, MD: Rowman and Littlefield Publishers, Inc., 1994. Business Ethics Quarterly, 8(01), 165-178.

Defourny, J., \& Nyssens, M. (2006). Conceptions of social enterprise in Europe and the United States: Convergences and divergences. Social Enterprise Journal, 1(1), 32-53.

Defourny, J., \& Nyssens, M. (2008). Social enterprise in Europe: Recent trends and developments. Social Enterprise Journal, 4(3), 202-228.

Desa, G., \& Basu, S. (2013). Optimization or bricolage? Overcoming resource constraints in global social entrepreneurship. Strategic Entrepreneurship Journal, 7(1), 26-49.

Devinney, T. M., Auger, P., \& Eckhardt, G. M. (2010). The myth of the ethical consumer hardback with DVD. Cambridge: Cambridge University Press.

Dey, P., \& Teasdale, S. (2016). The tactical mimicry of social enterprise strategies: Acting 'as if 'in the everyday life of third sector organizations. Organization, 23(4), 485-504.

Di Domenico, M.-L., Haugh, H., \& Tracey, P. (2010). Social bricolage: Theorizing social value creation in social enterprises. Entrepreneurship Theory and Practice, 34(4), 681-703.

Doherty, B., Davies, I. A., \& Tranchell, S. (2013). Where now for fair trade? Business History, 55(2), 161-189.

Doherty, B., Haugh, H., \& Lyon, F. (2014). Social enterprises as hybrid organizations: A review and research agenda. International Journal of Management Reviews, 16(4), 417-436.

Doherty, B., \& Tranchell, S. (2007). "Radical mainstreaming" of fairtrade: The case of the day chocolate company. Equal Opportunities International, 26(7), 693-711.

Ebrahim, A., Battilana, J., \& Mair, J. (2014). The governance of social enterprises: Mission drift and accountability challenges in hybrid organizations. Research in Organizational Behavior, 34, 81-100.

Eisenhardt, K. M. (1989). Building theories from case study research. Academy of Management Review, 14(4), 532-550.

Eisenhardt, K. M., \& Martin, J. A. (2000). Dynamic capabilities: What are they? Strategic Management Journal, 21(10/11), 1105-1121.

Elkington, J. (1997). Cannibals with forks. The triple bottom line of 21 st century. Oxford: Capstone Publishing Ltd.
European Commission (2017). Social Enterprises. http://ec.europ a.eu/growth/sectors/social-economy/enterprises_en. Accessed 30 March 2017.

Fairtrade Foundation (2014). Annual Report 2012-2013. Fairtrade Foundation, London.

França, C. L., Broman, G., Robèrt, K.-H., Basile, G., \& Trygg, L. (2016). An approach to business model innovation and design for strategic sustainable development. Journal of Cleaner Production, 140(part 1), 33-52. https://doi.org/10.1016/j.jclep ro.2016.06.124.

Frumkin, P., \& Andre-Clark, A. (2000). When missions, markets and politics collide: Values and strategy in the non-profit human services. Non-profit and Voluntary Sector Quarterly, 29(1), 141-163.

Geissdoerfer, M., Bocken, N. M. P., \& Hultink, E. J. (2016). Design thinking to enhance the sustainable business modelling process: A workshop based on a value mapping process. Journal of Cleaner Production, 135, 1218-1232.

Glaser, B. (1992). Basics of grounded theory analysis: Emergence vs forcing. Mill Valley: The Sociology Press.

Goulding, C. (2001). Grounded theory: A magical formula or a potential nightmare. The Marketing Review, 2(1), 21-34.

Grassl, W. (2012). Business models of social enterprise: A design approach to hybridity. ACRN. Journal of Entrepreneurial Perspectives, 1(1), 37-60.

Hahn, R., \& Ince, I. (2016). Constituents and characteristics of hybrid businesses: A qualitative, empirical framework. Journal of Small Business Management, 54(51), 33-52.

Haigh, N., \& Hoffman, A. J. (2014). The new heretics: Hybrid organizations and the challenges they present to corporate sustainability. Organization and Environment, 27(3), 223-241.

Hansmann, H. B. (1980). The role of non-profit enterprise. Yale Law Journal, 89(5), 835-898.

Hockerts, K. (2015). How hybrid organizations turn antagonistic assets into complementarities. California Management Review, 57(3), 83-106.

Hollander, C. S., Rassuli, K. M., Jones, B., \& Dix, L. F. (2005). Periodization in marketing history. Journal of Macromarketing, 25(1), 32-41.

ICO (2004). Lessons from the world coffee crisis: A serious problem for sustainable development. http://www.ico.org/documents/ ed1922e.pdf. Accessed 11 May 2017.

Jay, J. (2013). Navigating paradox as a mechanism of change and innovation in hybrid organizations. Academy of Management Journal, 56(1), 137-159.

Joyce, A., \& Paquin, R. L. (2016). The triple layered business model canvas: A tool to design more sustainable business models. Journal of Cleaner Production, 135, 1474-1486.

Khavul, S. (2010). Microfinance: Creating opportunities for the poor? The Academy of Management Perspectives, 24(3), $58-72$.

Kratz, M., \& Block, E. (2008). Organizational implications of institutional pluralism. In R. Greenwood, C. Oliver, K. Sahlin \& R. Suddaby (Eds.), The sage handbook of organizational institutionalism (pp. 243-275). Thousand Oaks: Sage.

Lehner, O. M., \& Nicholls, A. (2014). Social finance and crowd funding for social enterprises: A public-private case study providing legitimacy and leverage. Venture Capital, 16(3), 271-286.

Lüdeke-Freund, F., Freudenreich, B., Schaltegger, S., Saviuc, I., \& Stock, M. (2017). Sustainability-oriented business model assessment-A conceptual foundation. In Carayannis, E.G. and Sindakis, S. eds., In Analytics, innovation, and excellence-driven enterprise sustainability (pp. 169-206). Palgrave Macmillan US.

Lumpkin, G. T., Moss, T. W., Gras, D. M., Kato, S., \& Amezcua, A. S. (2013). Entrepreneurial processes in social contexts: How 
are they different, if at all? Small Business Economics, 40(3), 761-783.

Lyon, F., \& Fernandez, H. (2012). Strategies for scaling up social enterprise: Lessons from early years providers. Social Enterprise Journal, 8(1), 63-77.

Margiono, A., Margiono, A., Zolin, R., Zolin, R., Chang, A., \& Chang, A. (2017). A typology of social venture business model configurations. International Journal of Entrepreneurial Behaviour and Research, 24, 626-650.

Mason, C., \& Doherty, B. (2016). A fair trade-off? Paradoxes in the governance of fair-trade social enterprise. Journal of Business Ethics, 136(3), 451-469.

Miles, M. B., \& Huberman, A. M. (1994). Qualitative data analysis: An expanded sourcebook (2nd edn.). London: Sage Publications.

Mintel. (2008). Coffee-UK. London: Mintel International Group Limited.

Mintel. (2013a). Coffee-UK. London: Mintel International Group Limited.

Mintel. (2013b). Tea and other hot drinks-UK. London: Mintel International Group Limited.

Moizer, J., \& Tracey, P. (2010). Strategy making in social enterprise: The role of resource allocation and its effects on organizational sustainability. Systems Research and Behavioural Science, 27(3), 252-266.

Moss, T. W., Short, J. C., Payne, G. T., \& Lumpkin, G. T. (2011). Dual identities in social ventures: An exploratory study. Entrepreneurship Theory and Practice, 35(4), 805-830.

Mullins, D., Czischke, D., \& van Bortel, G. (2012). Exploring the meaning of hybridity and social enterprise in housing organisations. Housing Studies, 27, 405-417.

Obermiller, C., Burke, C., Talbott, E., \& Green, G. P. (2009). Taste great or more fulfilling: The effect of brand reputation on consumer social responsibility advertising for fair trade coffee. Corporate Reputation Review, 12(2), 159-176.

Osterwalder, A., \& Pigneur, Y. (2010). Business model generation: A handbook for visionaries, game changers, and challengers. New Jersey: John Wiley and Sons.

Osterwalder, A., Pigneur, Y., \& Tucci, C. L. (2005). Clarifying business models: Origins, present, and future of the concept. Communications of the Association for Information Systems (CAIS), $16,1-25$.

Pache, A. C., \& Santos, F. (2013). Inside the hybrid organization: selective coupling as a response to competing institutional logics. Academy of Management Journal, 56(40), 972-1001.

Phillips, N., Tracey, P., \& Jarvis, O. (2011). Bridging institutional entrepreneurship and the creation of new organizational forms: A multilevel model. Organization Science, 22(1), 60-80.

Rauter, R., Jonker, J., \& Baumgartner, R. J. (2015). Going one's own way: Drivers in developing business models for sustainability, Journal of Cleaner Production. https://doi.org/10.1016/j.jclep ro.2015.04.104.

Rogers, J. C., Simmons, E. A., Convery, I., \& Weatherall, A. (2012). Social impacts of community renewable energy projects: Findings from a woodfuel case study. Energy Policy, 42, 239-247.
Santos, F., Pache, A.-C., \& Birkholz, C. (2015). Making hybrids work. California Management Review, 57(3), 36-58.

Seelos, C., \& Mair, J. (2005). Social entrepreneurship: Creating new business models to serve the poor. Business Horizons, 48(3), 241-246.

Seibel, W. (2015). Studying hybrids: Sectors and mechanisms. Organization Studies, 36(6), 697-712.

Smith, B. R., Cronley, M. L., \& Barr, T. F. (2012). Funding implications of social enterprise: The role of mission consistency, entrepreneurial competence and attitude toward social enterprise donor behaviour. Journal of Public Policy and Marketing, 31(1), 142-157.

Smith, W. K., Gonin, M., \& Besharov, M. L. (2013). Managing socialbusiness tensions: A review and research agenda. Business Ethics Quarterly, 23(3), 407-442.

Spiggle, S. (1994). Analysis and interpretation of qualitative data in consumer research. Journal of Consumer Research, 21(3), 491-503.

Stähler, P. (2002). Business models as an unit of analysis for strategizing. In International workshop on business models, Lausanne, Switzerland, October 2002.

Teasdale, S. (2012). Negotiating tensions. How do social enterprises in the homelessness field balance social and commercial tensions? Housing Studies, 27(4), 514-532.

Teece, D. (2010). Business models, business strategy and innovation. Long Range Planning, 43(2-3), 172-194.

Thornton, P. H., Ocasio, W., \& Lounsbury, M. (2012). The institutional logics perspective. Oxford: Oxford University Press.

Tracey, P., \& Jarvis, O. (2007). Toward a theory of social venture franchising. Entrepreneurship Theory and Practice, 31(5), 668-685.

Vermeir, I., \& Verbeke, W. (2006). Sustainable food consumption: Exploring the consumer "attitude-behavioral intention" gap. Journal of Agricultural and Environmental Ethics, 19, 169-194.

Waldman, D. A., \& Bowen, D. E. (2016). Learning to be a paradoxsavvy leader. Academy of Management Perspectives, 30(3), 316-327.

Wilson, F., \& Post, J. E. (2013). Business models for people, planet (and profit): Exploring the phenomena of social business, a market-based approach to social value creation. Small Business Economics, 40(3), 715-737.

Witkowski, T. H., \& Jones, D. B. (2006). Qualitative historical research in marketing. In Belk, R. W. (Ed.). Handbook of qualitative research methods in marketing (pp. 70-82). Cheltenham: Edward Elgar Publishing.

Yin, R. (2003). Case study research: design and methods (4th edn.). London: Sage Publications.

Zott, C., Amit, R., \& Massa, L. (2011). The business model: Recent developments and future research. Journal of Management, 37(4), 1019-1042.

Zuckerman, E. W. (1999). The categorical imperative: Securities analysts and the illegitimacy discount. American Journal of Sociology, 104(5), 1398-1438. 